\title{
Ground-Water Levels in the Upper Three Runs and Gordon Aquifers in the General Separations Area, Savannah River Site, South Carolina, 1996
}

By LARRY G. HARRELSON, KEVIN J. CONLON, and MARY K. HARRIS

U.S. GEOLOGICAL SURVEY

Water-Resources Investigations Report 97-4217

Prepared in cooperation with the U.S. DEPARTMENT OF ENERGY 


\title{
U.S. DEPARTMENT OF THE INTERIOR BRUCE BABBITT, Secretary
}

\author{
U.S. GEOLOGICAL SURVEY
}

Mark Schaefer, Acting Director

The use of firm, trade, and brand names in this report is for identification purposes only and does not constitute endorsement by the U.S. Government.

For additional information write to:

District Chief

U.S. Geological Survey

Stephenson Center-Suite 129

720 Gracern Road

Columbia, South Carolina 29210-7651

Copies of this report can be purchased from:
U.S. Geological Survey
Branch of Information Services
Box 25286
Denver, Colorado 80225-0286 
4. Diagram showing generalized hydrogeology and beginning water-level measurements in observation wells open to selected aquifers beneath the SRS P27 well cluster in the General Separations Area, Savannah River Site, South Carolina, February 27, 1996

5. Graph showing water-level change in observation wells open to selected aquifers beneath the SRS P27 well cluster in the General Separations Area, Savannah River Site, South Carolina, February 27, 1996

6. Graph showing barometric pressure change at well cluster SRS P27 in the General Separations Area, Savannah River Site, South Carolina, February 27, 1996

7-9. Maps showing:

7. Configuration of the water-level surface for the Upper Three Runs aquifer (upper aquifer zone) beneath the General Separations Area, Savannah River Site, South Carolina, February 27, 1996.

8. Configuration of the water-level surface for the Upper Three Runs aquifer (lower aquifer zone) beneath the General Separations Area, Savannah River Site, South Carolina, February 27, 1996

9. Configuration of the water-level surface for the Gordon aquifer beneath the General Separations Area, Savannah River Site, South Carolina, February 27, 1996

\section{TABLES}

1. Water-level measurements in observation wells open to the Upper Three Runs aquifer (upper aquifer zone) in the General Separations Area, Savannah River Site, South Carolina, February 27, 1996

2. Water-level measurements in observation wells open to the Upper Three Runs aquifer (lower aquifer zone) in the General Separations Area, Savannah River Site, South Carolina, February 27, 1996

3. Water-level measurements in observation wells open to the Gordon aquifer in the General Separations Area, Savannah River Site, South Carolina, February 27, 1996

4. Water-level measurements in observation wells open to selected aquifers beneath the SRS P27 well cluster: BW-435, SRS P27D, Upper Three Runs aquifer (upper aquifer zone); BW-434, SRS P27C, Upper Three Runs aquifer (lower aquifer zone); and BW-433, SRS P27B, Gordon aquifer, in the General Separations Area, Savannah River Site, South Carolina, February 27, 1996.

5. Barometric pressure monitored at well cluster SRS P27 in the General Separations Area, Savannah River Site, South Carolina, February 27, 1996

6. Water-level measurements for piezometers in the General Separations Area, Savannah River Site, South Carolina, February 27, 1996. 48

7. Surface-water elevation measurements at selected surface-water sites in the General Separations Area, Savannah River Site, South Carolina, February 27, 1996 


\begin{tabular}{rll}
\hline Multiply & By & To obtain \\
& Length & \\
inch (in.) & 25.4 & millimeter \\
foot (ft) & 0.3048 & meter \\
& Area & square kilometer \\
square mile $\left(\mathrm{mi}^{2}\right)$ & 2.590 & \\
& & kilopascal \\
\hline
\end{tabular}

Sea level: In this report, "sea level" refers to the National Geodetic Vertical Datum of 1929--a geodetic datum derived from a general adjustment of the first-order level nets of the United States and Canada, formerly called Sea Level datum of 1929. 



\title{
Ground-Water Levels in the Upper Three Runs and Gordon Aquifers in the General Separations Area, Savannah River Site, South Carolina, 1996
}

\author{
By Larry G. Harrelson, Kevin J. Conlon, and Mary K. Harris ${ }^{1}$
}

\section{ABSTRACT}

On February 27, 1996, synoptic water-level and barometric pressure data were collected in the General Separations Area, Savannah River Site, South Carolina. These data were collected during a 9-hour period. Water levels were measured at 231 observation wells, 19 piezometers, and 16 surface-water sites. An automated data-collection system was used to continuously measure water levels and barometric pressure at the SRS P27 well cluster in Area $\mathrm{H}$. During the measurement period, barometric pressure varied 0.06 pound per square inch and water levels fluctuated 0.06 and 0.09 feet. Water levels did not fluctuate significantly due to barometric pressure changes during the measurement period.

Ground-water recharge to the upper and lower aquifer zones of the Upper Three Runs aquifer occurs in the topographically high interfluve areas of the General Separations Area on the Savannah River Site. The upper aquifer zone is unconfined and the lower aquifer zone is unconfined, semi-confined, and confined. Water levels in the upper aquifer zone are higher than water levels in the lower aquifer zone across the crest of the General Separations Area interfluve, suggesting that the unconfined and semi-confined parts of the lower aquifer zone receive recharge by leakage from the upper aquifer zone. The water-level surfaces of the upper and lower aquifer zones of the Upper Three Runs aquifer resembles the local

\footnotetext{
${ }^{1}$ Westinghouse Savannah River Company, Inc.
}

topography. Two ground-water divides trending approximately east-west and north-south are prominent features in the upper and lower aquifer zones of the Upper Three Runs aquifer. The ground-water divides roughly coincide with the topographically high areas of the interfluve. Both aquifer zones discharge to McQueen Branch, Crouch Branch, and the other tributaries of the Upper Three Runs and Fourmile Branch on the flanks of the General Separations Area interfluve.

Ground-water recharge to the Gordon aquifer is by lateral flow from areas to the east and northeast of the General Separations Area and by leakage from the lower aquifer zone of the Upper Three Runs aquifer. The Gordon aquifer is confined beneath all of the General Separations Area interfluve, except where the Gordon confining unit is breached by the incision of Upper Three Runs to the north and west of Area F. The potentiometric surface of the Gordon aquifer does not resemble the local topography.

\section{INTRODUCTION}

The Savannah River Site (SRS), a U.S. Department of Energy (DOE) facility, is located along the Savannah River approximately $60 \mathrm{mi}$ southwest of Columbia, S.C., and about $95 \mathrm{mi}$ from the Atlantic Ocean. The SRS is in the Upper Atlantic Coastal Plain physiographic province and occupies $310 \mathrm{mi}^{2}$ in parts of Aiken, Barnwell, and Allendale Counties in South Carolina (fig.1). 


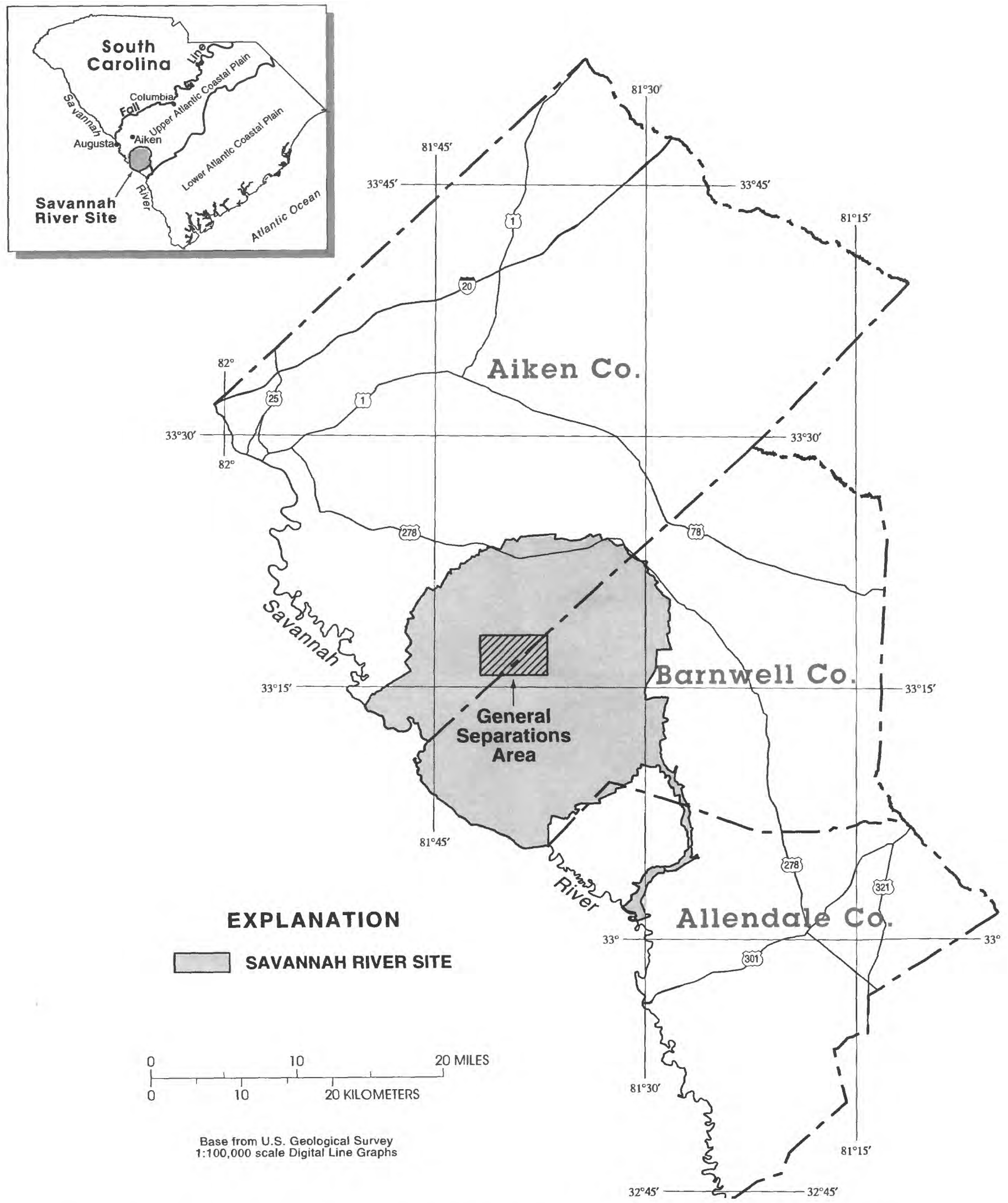

Figure 1. Location of the General Separations Area, Savannah River Site, South Carolina 
The General Separations Area (GSA) near the geographic center of the SRS, includes Areas F and $\mathrm{H}$, the Old Radioactive Waste Burial Grounds, the Low Level Radioactive Waste Facility (LLRWF) and the Mixed-Waste Management Facility (MWMF). The DOE plans to install a clay cap over the Old Radioactive Waste Burial Grounds, a soil cover over the LLRWF and the MWMF, and to activate extraction wells for pump-and-treat containment systems near the Area $\mathrm{F}$ and $\mathrm{H}$ seepage basins (fig. 2). These remedial actions could potentially change the shape of the water table and the potentiometric surfaces of aquifers beneath the GSA, and subsequently change the hydraulic gradients and the direction of ground-water flow in and around the remedial activity areas. In order to evaluate the effects of these remedial actions on the ground-water system beneath the GSA, the water-level surfaces of the upper and lower aquifer zones of the Upper Three Runs and Gordon aquifers need to be accurately defined prior to the implementation of these remedial actions.

In February 1996, the U.S. Geological Survey (USGS) in cooperation with the DOE investigated the hydrology in the vicinity of the GSA at the SRS. Synoptic ground-water, surface-water, and barometricpressure data were collected to map the water-level surfaces of the upper and lower aquifer zones of the Upper Three Runs and Gordon aquifers in the GSA.

\section{Purpose and Scope}

The purpose of this report is to describe the configuration of the water-level surfaces of the upper and lower aquifer zones of the Upper Three Runs and Gordon aquifers in the GSA. The configuration is shown on maps that represent the water-level surfaces prior to the installation of the clay cover over the Old Radioactive Burial Grounds and the soil cover over the LLRWF and the MWMF, and prior to the activation of extraction wells in the containment system for the Area $F$ and $\mathrm{H}$ seepage basins. These maps serve as a set of contemporary benchmarks for the GSA relative to these specific remedial activities.

This purpose was accomplished by assembling and evaluating existing geologic data; developing a local hydrologic framework; collecting and evaluating additional hydrologic data from selected observation wells, piezometers, and surface-water sites; and by interpreting the results of the survey.
The total thickness of the Coastal Plain strata beneath the GSA exceeds $800 \mathrm{ft}$ (Marine, 1979); however, only the Tertiary age strata are discussed in this report. The top of the Meyers Branch confining system acts as the major confining unit between the Tertiary age sediments and the underlying aquifers in Cretaceous age sediments; therefore, the Meyers Branch confining system is the vertical limit of this hydrologic investigation. The correlation of the geology and hydrogeology presented for the Tertiary age strata provides the hydrogeologic framework required to describe the configuration of the water-level surfaces of the upper and lower aquifer zones of the Upper Three Runs and Gordon aquifers in the GSA.

\section{General Description of Study Area}

The study area comprises approximately $19 \mathrm{mi}^{2}$ in the central part of the SRS (fig. 1) and includes the industrial and waste-management facilities of the GSA. The study area is located on a broad interfluve between Upper Three Runs and Fourmile Branch (fig. 2). The eastern boundary of the study area is McQueen Branch. The western boundary is about half a mile west of Burma Road.

The study area is in the Atlantic Coastal Plain physiographic province. Sediments beneath the study area include Late Cretaceous and Tertiary age strata and are predominantly interlayered sequences of sand and clay (Siple, 1967; Dennehy and others, 1989; Fallaw and Price, 1995). The Tertiary section includes a few thin beds of partially lithified carbonate and silicified carbonate (Thayer, Smits, Parker, and others, 1993).

\section{Previous Investigations}

Several regional and SRS-specific reports describe the geology and hydrology of the GSA. Regional reports include Sloan (1908), Cooke (1936), Cooke and MacNeil (1952), Siple (1967), Daniels (1974), Marine and Root (1978), Bechtel Corporation (1982), Colquhoun and others (1983), Faye and Prowell (1982), Huddlestun (1982), Prowell, Christopher, and others (1985), Prowell, Edwards, and Frederiksen (1985), Steele (1985, 1992), Logan and Euler (1989), Nystrom and others $(1989,1991)$, Aadland and Bledsoe, (1990), Robertson, (1990), Aadland and others (1991, 1995), Fallaw and others (1989), Fallaw, Price, 
and Sexton (1992), Fallaw, Snipes, and others (1992), Fallaw and others (1992a), Fallaw and others (1992b), Fallaw and Price (1992, 1995), Harris and others (1993), Laws and others (1992), Price and others (1992), Robertson and Thayer (1992), Snipes and others (1992, 1993), Thayer and Harris (1992), Prowell, (1994), and Harrelson and others (1997). The geology and hydrology of the GSA are described in site-specific reports by Christl (1964), Marine (1979), Root (1980, 1981), D'Appolonia (1981, 1982), Sargent (1984), Cook (1986), Dennehy and other (1989), Bledsoe and others (1990), Harris and others (1992), Westinghouse Savannah River Company (1992), Thayer, Smits, Harris, and others (1993), and Thayer, Smits, Parker, and others (1993). Reports on ground-water flow modeling in the study area include Parizek and Root (1984), Buss and others (1987), Duffield and others (1987), Spalding and others (1987), and Geotrans, Inc. (1988a, 1988b, 1988c, 1988d).

\section{Acknowledgments}

The authors thank Mark B. Amidon, Kenneth L. Dixon, Robert (Bob) Hunter, Keith Johnson, and Brian B. Looney of Westinghouse Savannah River Company, Inc., (WSRC) for their invaluable assistance in providing data for this report.

\section{GEOLOGY}

The Tertiary strata described in this section include in ascending order the Lang Syne Formation, the Snapp Formation, the Fourmile Branch Formation, the Congaree Formation, the Warley Hill Formation, the Tinker Formation/Santee Limestone, the Clinchfield Formation, the Dry Branch Formation, the Tobacco Road Formation, and the "upland" unit (fig 3). The "upland" unit is the youngest geologic unit in the study area. A comparison with previous stratigraphic nomenclature and lithologies beneath the study area are presented for each unit.

\section{Lang Syne Formation}

The type locality of the Lang Syne Formation and its correlation to the SRS are described in Sloan (1908), Padgett (1980), Colquhoun and others (1983), Howell (1985), Muthig and Colquhoun (1988), Colqu- houn and Muthig (1991), and Nystrom and others, (1991). This lithologic unit has formerly been termed the Ellenton Formation in the SRS region by Siple (1967), Prowell, Edwards, and Frederiksen (1985), and Dennehy and others (1989). The Lang Syne was raised to a formation by Fallaw and Price (1992), replacing the use of the term Ellenton in the SRS region.

The Lang Syne Formation consists of dark gray and black, lignitic clays with interbeds of poor to mod erately sorted micaceous, lignitic muddy quartz sand, and pebbly sand. The clays are predominantly fissile with micaceous silt and fine sand laminae (Fallaw and Price, 1995). The gray and black lignitic fissile clay is interpreted as lagoon or bay deposits. The micaceous, lignitic muddy quartz sand and pebbly sands are interpreted to be upper delta plain sediments in the GSA region of the SRS. Lower delta plain and prodelta facies are present southeast of the GSA (Fallaw and Price, 1995).

\section{Snapp Formation}

The Snapp Formation at the SRS is correlative to the Williamsburg Formation, as given by Colquhoun and others (1983), Steele (1985), and McClelland (1987). The Snapp was raised to a formation by Fallaw and Price (1995).

The Snapp lithologies are primarily silty, medium to coarse quartz sand with beds of oxidized clay. Minor lithologies are dark, micaceous, lignitic sand (Aadland and others, 1995). The type section for the Snapp Formation is recognized in the SRS P22 core in the southeastern part of the SRS where it attains a thickness of $50 \mathrm{ft}$. According to Fallaw and Price (1995), the Snapp Formation accumulated in an upper delta plain environment and appears to pinch out in the central portion of SRS near the GSA.

\section{Fourmile Branch Formation}

Fallaw and Price (1995) correlated the Fourmile Branch Formation in the SRS region to the Fishburne Formation as given by Gohn and others (1983). The sand was initially designated the Fourmile Member of the Fishburne Formation (Fallaw and others, 1992b). Fallaw and Price (1995) recognized the Fourmile Branch Formation and described a type section in well MWD 3A near the study area (fig.2). 


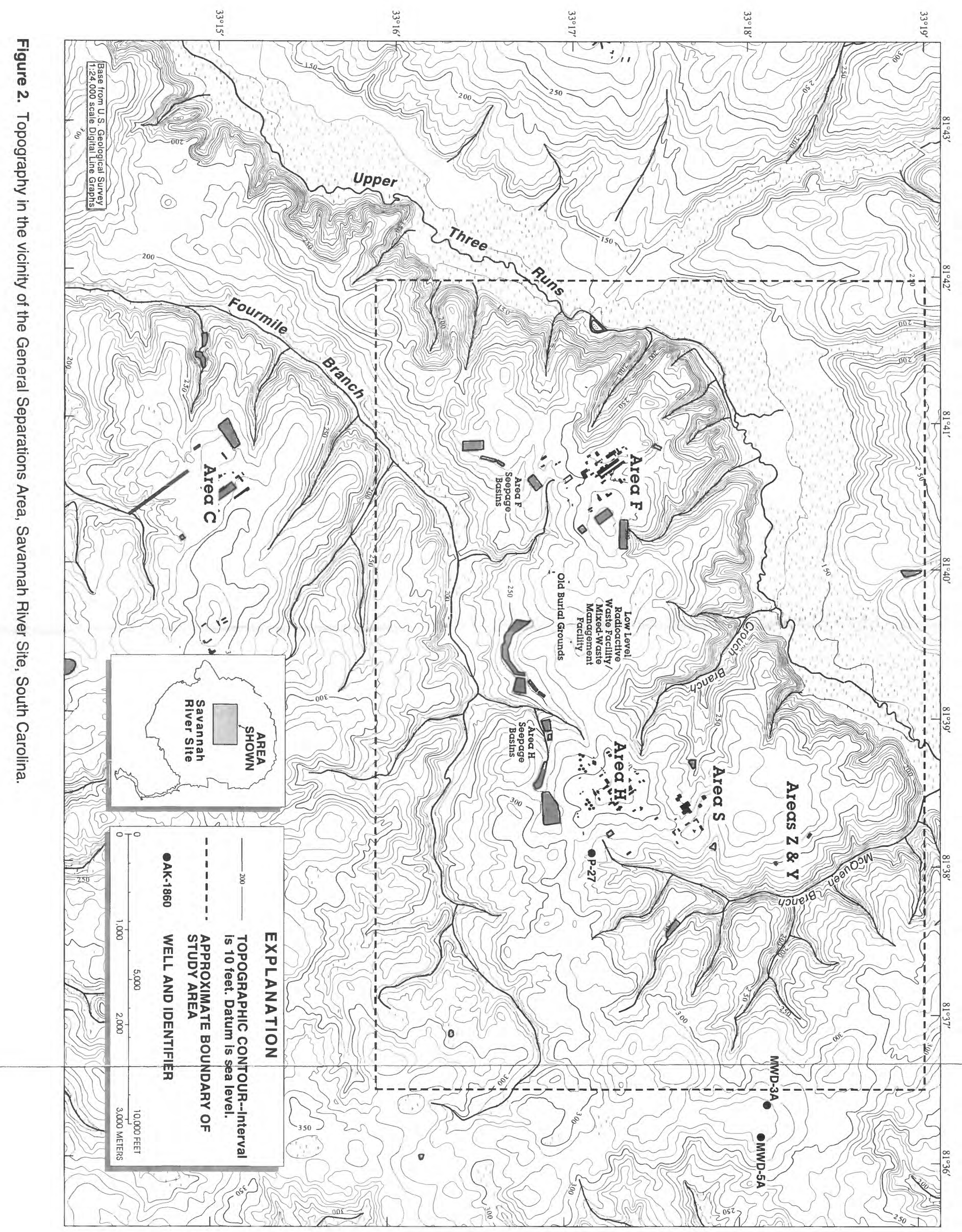




\begin{tabular}{|c|c|c|c|}
\hline \multicolumn{2}{|c|}{ GEOLOGY } & \multicolumn{2}{|c|}{ HYDROGEOLOGY } \\
\hline \multicolumn{2}{|c|}{ "Upland" Unit } & \multirow{3}{*}{$\begin{array}{l}\text { Upper } \\
\text { aquifer } \\
\text { zone }\end{array}$} & \multirow{6}{*}{$\begin{array}{l}\text { Upper } \\
\text { Three } \\
\text { Runs } \\
\text { aquife }\end{array}$} \\
\hline Tobacco Road & Formation & & \\
\hline \multirow{2}{*}{ Dry Branch Formation } & $\begin{array}{l}\text { Iwinton Sand Member } \\
-\bar{T} \text { - }\end{array}$ & & \\
\hline & - INggs Liay Memoer & \multirow{3}{*}{$\begin{array}{l}\text { Lower } \\
\text { aquifer } \\
\text { zone }\end{array}$} & \\
\hline \multicolumn{2}{|c|}{ Clinchfield Formation } & & \\
\hline \multicolumn{2}{|c|}{ Tinker Formation/Santee Limestone } & & \\
\hline \multicolumn{2}{|c|}{ Warley Hill Formation } & \multicolumn{2}{|c|}{$\begin{array}{l}\text { Gordon confining unit } \\
\text { "green clay" }\end{array}$} \\
\hline \multicolumn{2}{|c|}{ Congaree Formation } & \multirow{2}{*}{\multicolumn{2}{|c|}{$\begin{array}{l}\text { Gordon } \\
\text { aquifer }\end{array}$}} \\
\hline \multicolumn{2}{|c|}{ Fourmile Branch Formation } & & \\
\hline \multicolumn{2}{|c|}{ Snapp Formation } & \multirow{2}{*}{\multicolumn{2}{|c|}{$\begin{array}{l}\text { Meyers Branch } \\
\text { confining system }\end{array}$}} \\
\hline \multicolumn{2}{|c|}{ Lang Syne Formation } & & \\
\hline
\end{tabular}

Figure 3. Generalized correlation of the geology and hydrogeology in the General Separations Area, Savannah River Site, South Carolina. 
In the SRS, region the Fourmile Branch lithologies are primarily moderately to well sorted sand with clay beds near the middle and at the top of the unit. The sand is very coarse to fine, with pebbly zones, especially near the base. Glauconite, up to 5 percent, and weathered feldspar are present. The Fourmile Branch Formation averages $30 \mathrm{ft}$ in thickness. Glauconite and dinoflagellate indicate that this unit is a shallow marine deposits (Fallaw and Price, 1995).

\section{Congaree Formation}

The term "Congaree Phase" was first introduced by Sloan (1908) to describe the shales, sands, and buhrstones of early and middle Eocene age overlying the "Black Mingo Phase" and underlying the "Warley Hill Phase" located at Warley Creek, Calhoun County, S.C. Cooke and MacNeil (1952) assigned the Congaree to the early middle Eocene and raised it to formational rank.

The early middle Eocene Congaree Formation has been traced from the Congaree valley in east-central South Carolina to the SRS area (Colquhoun and others, 1982, 1983). The Congaree crops out along Upper Three Runs near its juncture with Tinker Creek on the SRS (Nystrom and Willoughby, 1982; Willoughby, 1983, 1985, 1986; Nystrom, 1986; Nystrom and others, 1989). Downdip from these outcrops, the Congaree occurs only in the subsurface (Nystrom and others, 1989). At the SRS the unit consists of yellow, orange, tan, gray, and greenish gray, iron-stained, moderately well to poorly sorted, fine to coarse quartz sand with discontinuous lenses of montmorillonitic clay (Colquhoun and Johnson, 1968). Pebbly layers, clay clasts, calcareous sand, and glauconite also are present sporadically. The base of the formation is unconformable. The lower middle Eocene deposits become increasingly calcareous between the SRS and the coast (Colquhoun, and others, 1983; Harris and others, 1992).

The Congaree Formation has been interpreted to be a marine shelf deposit because of the occurrence of marine fossils, phosphate, and glauconite (Robertson and Thayer, 1992). The equivalent of the Congaree to the northwest of the SRS has been mapped as the Huber Formation (Nystrom and Willoughby, 1982). The Huber Formation is more micaceous and poorly sorted, which indicates deposition in fluvial and deltaic environments. The Congaree averages $82 \mathrm{ft}$ thick in the SRS area (Robertson, 1990) and is about $60 \mathrm{ft}$ thick in well MWD 3A (fig. 2) near the study area (Fallaw and Price, 1995). The unit increases in thickness to the north and south. A maximum thickness of $125 \mathrm{ft}$ just south of the SRS was reported by Robertson (1990).

\section{Warley Hill Formation}

Sloan (1908) was the first to use the term "Warley Hill Phase." Cooke and MacNeil (1952) applied the name "Warley Hill Marl" for glauconitic beds occurring between the Congaree and McBean Formations. Pooser (1965) considered the term "marl" to be inappropriate for the overall lithology of the unit and proposed the name Warley Hill Formation. Both the glauconitic sand and the clay at the top of the Congaree are assigned to the Warley Hill Formation at SRS (Fallaw and Price, 1995).

The Warley Hill Formation unconformably overlies the Congaree Formation and consists of approximately $15 \mathrm{ft}$ of poorly to well-sorted quartz sand, glauconitic sands, clays, sandy clay, and clayey sands (Fallaw and Price, 1995). The sediments generally have a distinct dark green color due to glauconite. The clay minerals in the matrix include illite and smectite (Dennehy and others, 1989). The green sand and clay beds of the Warley Hill are part of a unit that is informally referred to as the "green clay" in many SRS reports (Fallaw and Price, 1995).

Pooser (1965) considered the Warley Hill clastics to be shallow to deep shelf deposits in the study area, generally forming in deeper water than the underlying Congaree Formation. Fallaw and Price (1995) considered the glauconite and dinoflagellates to be indicative of shallow marine conditions and the muddier sands to represent a lower-energy environment than the Congaree.

\section{Tinker Formation/Santee Limestone}

Lyell (1845) was the first to use the term "Santee" for limestones exposed along the Santee River in South Carolina. The terms "McBean Formation" and "Lisbon Formation" have been applied to these sediments, but the term "Santee" of Sloan (1908) is generally accepted. Cooke (1936) coined the term Santee Limestone with formational status. 
Cooke (1936) assigned the unit to upper Eocene age, but Cooke and MacNeil (1952) reassigned it to the middle Eocene as the equivalent of the Gulf States' Cook Mountain Formation of the Claiborne Group. The most recent interpretation of stratigraphic units for the Santee Limestone is that this part of the middle Eocene section consists of three laterally gradational units (Fallaw and Price, 1995): the Tinker Formation, the Santee Limestone, and the informally named "Blue Bluff Unit" (Huddlestun and Hetrick, 1985). The Santee Limestone is a downdip calcareous facies, whereas the Tinker Formation represents a correlative facies that occur in the updip part of the SRS. The "Blue Bluff Unit" occurs to the southeast of the SRS and interfingers with and grades into the Santee Limestone (Fallaw and Price, 1995). The "Blue Bluff Unit" is not present in the GSA and is not addressed in this study. The Tinker Formation/Santee Limestone is about $70 \mathrm{ft}$ thick in the center of the SRS (Aadland and others, 1995).

The Tinker Formation consists of fine and medium, tan, orange, and yellow, poorly to well sorted, and slightly to moderately indurated sands with interbedded clays. This unit is slightly glauconitic in places and contains abundant heavy minerals. The sands suggest barrier and inner neritic environments, while the silts and clays were probably deposited in bays, lagoons, and low energy shelf areas (Fallaw and Price, 1995).

The Santee Limestone consists of moderately sorted, yellow and tan sand, calcareous sands and clays, carbonates, and clay. Limestone is much more abundant in the downdip part of the SRS, sporadic and pod-like in the middle of the GSA, and missing in updip sections to the northwest. The carbonates represent shallow open-marine environments.

\section{Clinchfield Formation}

The Clinchfield Formation generally consists of medium-grained, well-sorted, poorly consolidated, massively bedded quartz sand (Huddlestun and Hetrick, 1979). At the SRS, this unit has only been identified when the carbonates of the Griffins Landing Member of the Dry Branch Formation and the Santee Limestone are present. According to Fallaw and Price (1995), the sands are tan and yellow, poorly to well sorted, and fine to coarse at the SRS and are only $10 \mathrm{ft}$ thick at well MWD 5A (fig. 2).

\section{Dry Branch Formation}

The Dry Branch Formation is divided into the Griffins Landing Member, the Twiggs Clay Member, and the Irwinton Sand Member (Aadland and others, 1995). At the SRS, the formation is approximately 50 $\mathrm{ft}$ thick near the northwestern site boundary and approximately $80 \mathrm{ft}$ thick near the southeastern site boundary (Fallaw and Price, 1995). Near the center of the SRS, the Dry Branch Formation is approximately $60 \mathrm{ft}$ thick (Aadland and others, 1995).

The Griffins Landing Member is composed of mostly tan or green, slightly indurated, calcareous quartz sand, and slightly calcareous clay (Fallaw and Price, 1995). The unit is widespread in the southeastern part of the SRS, but becomes sporadic in the center where it pinches out. The Griffins Landing Member appears to have formed in shallow marine to lagoonal environments (Aadland and others, 1995).

The Twiggs Clay Member is not mappable in the area near the SRS, but lithologically similar clay is present at various stratigraphic levels in the Dry Branch Formation. The tan, light-gray, and brown clay is not continuous over long distances. The Twiggs Clay lithology is referred to as the "tan clay" in many SRS reports (Aadland and other, 1995).

The Irwinton Sand Member is composed of tan, yellow, and orange, moderately sorted, quartz sand with abundant interlaminated and interbedded clay in places (Fallaw and Price, 1995). The tan, light-gray, and brown clay beds are discontinuous and, like the Twiggs Clay Member, also are referred to as the "tan clay" in many SRS reports (Aadland and others, 1995).

The Irwinton sand beds and interbedded clays are interpreted as shallow marine deposits, including barrier, lagoonal, and marsh environments (Smith, 1979; Fallaw and Price, 1995).

\section{Tobacco Road Formation}

The Tobacco Road Formation is primarily fine to coarse sand and varies from well sorted to poorly sorted with flat quartz pebbles at the base in some places (Fallaw and Price, 1995). Variations of clay, chert, mica, limestone, and heavy-mineral content exist locally (Huddlestun and Hetrick, 1979). Bedding can be massive, burrowed, or bioturbated (Logan and Euler, 1989). Fallaw and Price (1995) interpreted a transitional, low energy marine environment, possibly 
a tidal flat, on the basis of the bedding characteristics and presence of Ophiomorpha, a trace fossil.

\section{"Upland" Unit}

The term "upland" unit has been widely used in the Coastal Plain of South Carolina for the poorly sorted, silty, clayey and pebbly sand, and conglomerates that occur at higher elevations within the study area. At the SRS the "upland" unit has been called the Hawthorn Formation (Siple, 1967), or the Altamaha Formation (Huddlestun and Hetrick, 1988; Nystrom and Willoughby, 1992; Fallaw and Price, 1995). It is believed that the unit is correlative to the Chandler Bridge Formation near the coast (Colquhoun and others, 1994). Because the age of the unit is still controversial, this report uses the informal name "upland" unit.

Colquhoun and others (1994) suggested that the "upland" unit was similar in texture and composition to the Tobacco Road and Dry Branch Formations. They believed that the unit was part of the same transgressive/regressive cycle as the Tobacco Road and Dry Branch Formations.

\section{HYDROGEOLOGY}

The hydrogeologic framework for this report is restricted to the upper and lower aquifer zones of the Upper Three Runs aquifer, the "tan clay" confining zone, the Gordon confining unit, the Gordon aquifer, and the Meyers Branch Confining System as defined for the SRS by Aadland and others (1995). The Upper Three Runs aquifer is divided into three units that are informally named the upper aquifer zone, the "tan clay" confining zone, and the lower aquifer zone (Aadland and others, 1995). The Gordon aquifer is separated from the Upper Three Runs aquifer by the Gordon confining unit or "green clay." The underlying Gordon aquifer consists of all saturated strata that occur between the Gordon confining unit and the Meyers Branch Confining System. The top of the Meyers Branch Confining System defines the lower boundary of this investigation (fig. 3).

Each hydrogeologic unit is described in terms of its correlation to the geologic section (fig. 3) (Dennehy and others, 1989; Aadland and others, 1995). The saturation and confining conditions are described for each aquifer and aquifer zone. The units are discussed in descending order.

\section{Upper Three Runs Aquifer}

This aquifer includes all sediments from land surface down to the top of the Gordon confining unit (Aadland and others, 1995). In the vicinity of the GSA, the Upper Three Runs aquifer is correlative to the "upland" unit, the Tobacco Road Formation, Dry Branch Formation, Clinchfield Formation, and most of the Tinker Formation/Santee Limestone (fig. 3). The Upper Three Runs aquifer is divided into the upper and lower aquifer zones that are separated by the "tan clay" confining zone.

\section{Upper Aquifer Zone}

The upper aquifer zone is part of the Upper Three Runs aquifer between land surface and the top of the "tan clay" confining zone (fig. 3). This unit includes the sediments of the "upland" unit, the Tobacco Road Formation, and part of the Dry Branch Formation. This unit is equivalent to the Barnwell aquifer and aquifer zone $\mathrm{IIB}_{2}$ (Dennehy and others, 1989; Thayer, Smits, Harris, and others, 1993). The upper aquifer zone includes both a unsaturated and a saturated interval and is unconfined across the GSA (Thayer, Smits, Harris, and others, 1993). In this study, the water-level data collected from this hydrogeologic unit are mapped as an unconfined water-level surface.

\section{"Tan Clay" Confining Zone}

The "tan clay" confining zone is correlative to the "tan clay" interval of the Dry Branch Formation as described by Fallaw and Price (1995). Like the other Coastal Plain strata, the "tan clay" and the rest of the Dry Branch Formation generally have a southeasterly structural dip. Outcrops of the Dry Branch Formation are at higher elevations in the Upper Three Runs valley along the north and west sides of the GSA and at lower elevations in the Fourmile Branch valley along the south and southeast sides of the GSA (Prowell, 1994). 
The clay is present at various intervals and is not continuous over long distances (Aadland and others, 1992; Harris and others, 1993). Where the "tan clay" is not present, the upper and lower aquifer zones are in direct contact, and therefore, the vertical movement of water is not impeded. Dennehy and others (1989) mapped the "tan clay" confining zone between their Barnwell and McBean aquifers and recognized that the zone was absent in the vicinity of the Area $S$ and McQueen Branch (fig. 2). This zone is equivalent to the IIB ${ }_{1}-I I B_{2}$ confining zone reported by Thayer, Smits, Harris, and others (1993).

\section{Lower Aquifer Zone}

The lower aquifer zone is the part of the Upper Three Runs aquifer below the "tan clay" confining zone. This unit includes the sediments of the Dry Branch Formation below the "tan clay," the Clinchfield Formation, and most of the Tinker Formation/Santee Limestone. This unit is equivalent to the McBean aquifer and aquifer zone IIB $_{1}$ (Dennehy and others, 1989; Thayer, Smits, Harris, and others, 1993).

This unit is saturated and is either confined, semi-confined, or unconfined. Outcrops of the Tinker Formation/Santee Limestone (McBean Formation) were mapped along the north and west sides of the GSA (Prowell, 1994). Water-level data from this zone of the Upper Three Runs aquifer were mapped as a distinct water-level surface, except in the outcrop area along the Upper Three Runs valley where the upper and lower zones act as one aquifer and discharge into the Upper Three Runs. In this area, the water-level data are interpreted as unconfined. Surface-water elevation measurements were used to map the water-level surface along streams for the upper and lower aquifer zones.

\section{Gordon Confining Unit}

The Gordon confining unit is correlated to the "green clay" (Root, 1980; Snipes and others, 1992) and is the hydrogeologic equivalent of the "green clay" confining unit or the IIA-IIB confining unit (Dennehy and others, 1989; Thayer, Smits, Harris, and others, 1993). Fallaw and Price (1995) described the "green clay" interval as part of the Congaree Formation, the Warley Hill Formation, and the Tinker Formation/ Santee Limestone. The Gordon confining unit in the GSA includes the "green clay" and some of the fine grained calcareous beds of the Warley Hill Formation and Tinker Formations.

This unit crops out in the stream bed of Upper Three Runs to the north of Area F and just downstream of the confluence with Crouch Branch (fig. 2). Downstream of the outcrop, the Gordon confining unit is breached by the incision of the Upper Three Runs valley. This unit is not exposed along Fourmile Branch.

\section{Gordon Aquifer}

The Gordon aquifer includes sediments of the Fourmile Branch and Congaree Formations, depending on the thickness and stratigraphic distribution of the "green clay" lithology. The Gordon aquifer is equivalent to the Congaree and IIA aquifers (Dennehy and others, 1989; Logan and Euler, 1989; Thayer, Smits, Harris, and others, 1993).

The Gordon aquifer is saturated and confined, except for an area in the downstream reach of the Upper Three Runs below the outcrop of the Gordon confining unit. Water levels from this interval are interpreted as a confined water-level surface.

\section{Meyers Branch Confining System}

The Meyers Branch confining system includes the Lang Syne and Snapp Formations (Aadland and others, 1992, 1995). The base of the Gordon aquifer is defined by the top of the clay lithologies of either the Snapp Formation or, in the absence of the clays of the Snapp Formation, the Lang Syne Formation. This unit is equivalent to the Ellenton confining unit and the I-II confining system (Dennehy and others, 1989; Thayer, Smits, Harris, and others, 1993).

\section{METHODS}

The entire inventory of wells and several surface-water sites in the GSA study area were reviewed as potential water-level measurement sites. Several of the wells previously inventoried in the GSA (Westinghouse Savannah River Company, 1995; Harrelson and others, 1997) were abandoned before February 27 , 1996 , and were not available for use during the waterlevel data collection period. Several other wells in the study area also were eliminated as potential water-level measurement sites because of the presence of hazard- 
ous ground-water contamination in the wells. In addition to the ground- and surface-water data, barometric pressure data were collected by the USGS. The WSRC collected water-level data from selected wells in restricted areas, as well as from piezometers in and around the wetlands of Fourmile Branch.

\section{Well-Numbering Systems}

Each well in the GSA has been assigned three well identifiers. The three well-numbering systems are used by the USGS, the South Carolina Department of Natural Resources (SCDNR), and the DOE/WSRC.

The USGS and the SCDNR share a common well-numbering system that is called the USGS identifier in this report. Wells inventoried in South Carolina are sequentially numbered in each county using an alphanumeric well designation. The alpha prefix refers to the county and the number refers to the chronological order in which wells were inventoried in that county. Thus, the 435th well inventoried in Barnwell County would be designated BW-435.

The SCDNR identifiers are assigned to wells on the basis of a latitude- and longitude-grid system (Logan and Euler, 1989). This grid system divides South Carolina into a matrix of cells with the dimensions of 5-minutes latitude and longitude. Each of these cells has a corresponding number and upper-case letter(s), for example, 38X. The cells are further divided into 25 cells with dimensions of 1 -minute latitude and longitude, each having a corresponding lowercase letter "a" through " $y$ ", for example, 38X-n. As wells are located within the 1-minute grid, a sequential number is assigned to each well in the 1-minute grid. Thus, the $63 \mathrm{~d}$ well inventoried in $38 \mathrm{X}-\mathrm{n}$ would be assigned the number 38X-n63.

The SRS identifier in this report is the same as the Well Data File code of the SRS (Westinghouse Savannah River Company, 1995). The SRS identifier is an alphanumeric system. An alphanumeric abbreviation is assigned to areas on the SRS (for example, "FSB" is for wells near the Area F Seepage Basin) or special well series (for example, the P-wells for the SRS Baseline Hydrogeologic Investigation). the wells in each area or special well series are sequentially numbered.

In this report each well has three identifiers: a USGS identifier, a SCDNR identifier, and a DOE/ WSRC identifier. Thus, BW-435, 38X-n63, and P27D identify the same well. All three well-identifiers are shown in tables 1,2, and 3 (at end of report). The wells in the tables are organized by the USGS identifier. Piezometers in table 4 (at end of report) are identified and organized by the SRS identifier.

\section{Aquifer Assignments}

WSRC provided data for approximately 127 corehole sites to select and map the elevation of the top of the "tan clay" confining zone, the lower aquifer zone of the Upper Three Runs aquifer, the Gordon "green clay" confining unit, the Gordon aquifer, and the Meyers Branch Confining System (Mark B. Amindon, Westinghouse Savannah River Company, written commun., 1995). Each map was digitized and entered in an ARC/INFO (a registered software package of Environmental Systems Research Institute) data base to create a three-dimensional projection in a computerized matrix of a Geographic Information System (GIS). The GIS was used to compare the elevation of the open or screened interval(s) in each well to the elevation of the top of each hydrogeologic unit to determine the aquifer assignment for each well. If a well was screened in more than one aquifer or screened in a confining unit, the well was not used for this study.

\section{Data Collection}

On February 27, 1996, water levels were measured in 231 wells, 19 piezometers, and 16 surfacewater sites in the vicinity of the GSA. Calibrated electric and steel tapes, with a resolution of $0.01 \mathrm{ft}$ were used to measure the ground- and surface-water levels, respectfully. The field measuring point, a position on each well head from which depth to water is measured, is a defined height above the concrete well pad or land surface. The height of each measuring point was determined in the field and compared to the published measuring point for verification (Westinghouse Savannah River Company, 1995). The height of the measuring point and the height of the concrete well pad were subtracted from the measured depth to water to determine the depth to water below land surface. The depth to water below land surface was subtracted from the published land-surface elevation at each well to obtain the elevation of the water. 
For the 16 surface-water sites, a temporary elevation benchmark was established at each site and used to convert measured water level to elevation of water level. The surface-water elevations were used to map water-level surfaces of the upper and lower aquifer zones for the Upper Three Runs aquifer.

Barometric pressure near the earth's surface can affect the position of water levels in wells that are open to confined aquifers (Ferris and others, 1962). An automated data collection system was used to collect barometric pressure and water levels in selected wells at the SRS P-27 well cluster (fig. 2). The automated data system recorded water levels and barometric pressure every 5 minutes.

\section{GROUND-WATER LEVELS}

The ground water that saturates the aquifers and confining units moves in response to differences in hydraulic head. The direction of ground-water flow can be inferred from mapped water-level contour lines. Flow is perpendicular to the contour lines and moves in the direction of declining hydraulic head.

Changes in water levels in the monitored wells at the SRS P27 well cluster (fig. 4) were 0.06 and $0.09 \mathrm{ft}$ during the 9 -hour measurement period (fig. 5; table 4 at end of report). The barometric pressure varied only slightly (fig. 6; table 5 at end of report) and fluctuated by less than $0.06 \mathrm{lb} / \mathrm{in}^{2}$. There were no significant changes in the water levels due to the barometric pressure variations during the study period; therefore, water-level corrections for barometric effects were not applied.

\section{Upper Three Runs Aquifer}

A total of 153 water-level measurements were collected from observation wells, piezometers, and surface-water sites (tables 1, 6, and 7 at end of report) in the upper aquifer zone and 61 water-level measurements were collected from observation wells in the lower aquifer zone (table 2 at end of report). The waterlevel surface for the upper aquifer zone represents the top of the saturated zone and is assumed to be unconfined. The lower aquifer zone is confined to semi-confined and is unconfined in the outcrop areas of the Upper Three Runs and Fourmile Branch valleys.

The configuration of the water-level surface in the upper and lower aquifer zones (figs. 7 and 8) strongly resemble the local topography (fig. 2). The contours suggest that the water levels in both zones indicate lower hydraulic gradients beneath the broad crest of the interfluve and higher hydraulic gradients beneath the flanks of the interfluve in the valleys of Fourmile Branch and Upper Three Runs. The highest water-level elevations observed from both zones were in Area $\mathrm{H}$. The contours indicate two ground-water divides in the upper aquifer zone of the Upper Three Runs aquifer (fig. 7). One of the divides has an eastwest trend from Area $\mathrm{H}$ to Area $\mathrm{F}$. The other divide has a north-south trend from Area $Z$ and $Y$ to Area $S$. Ground-water data for the water-level surface in the lower aquifer zone are better defined for the area west of Area $\mathrm{H}$ and defines an east-west divide. In areas north of Area $\mathrm{H}$, water levels of both aquifer zones are interpreted as the water table and are presented as an approximation of the water-level surface (fig. 8). Even though based on limited data, the water-level contours are useful for determining the water-level gradient and inferring the location of the north-south trending divide from Areas $Z$ to Area $S$. The divides on both maps roughly coincide with the topographically high areas of the interfluve. McQueen Branch, Crouch Branch, and many of the smaller, ephemeral creeks intersect the water level in both aquifer zones.

The configuration of the contours suggests that recharge to the upper and lower aquifer zones occurs largely within the interfluve. Both aquifer zones discharge to the north along McQueen Branch, Crouch Branch, and unnamed tributaries along Upper Three Runs and to the south along Fourmile Branch and unnamed tributaries. Where water levels in the upper aquifer zone are higher than water levels in the lower aquifer zone, the semi-confined and confined parts of the lower aquifer zone in this area receive recharge by leakage from the upper aquifer zone. Where water levels in both zones are equal, the lower aquifer zone is considered to be semi-confined to unconfined. 


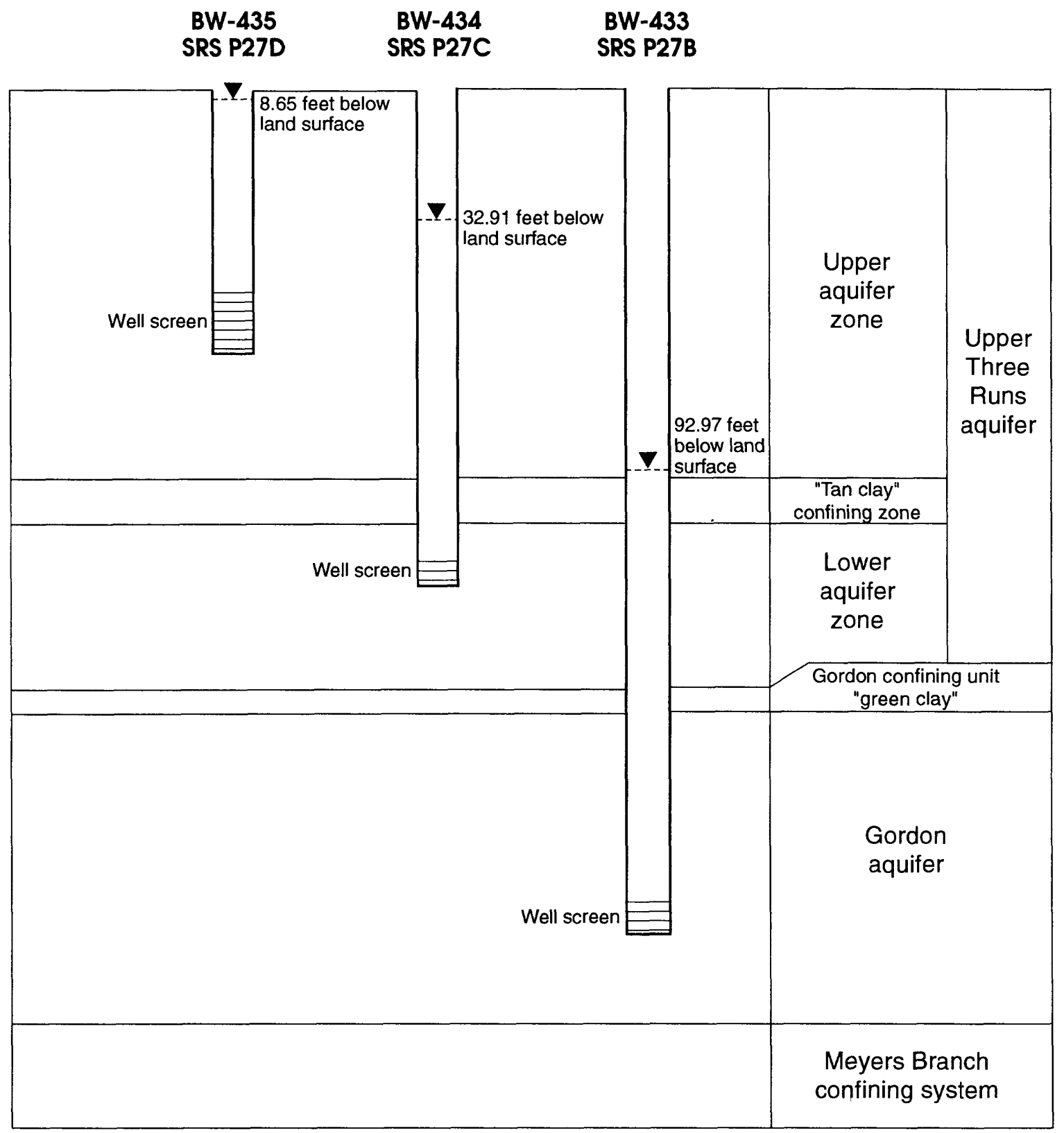

Figure 4. Generalized hydrogeology and beginning water-level measurements in observation wells open to selected aquifers beneath the SRS P27 well cluster in the General Separations Area, Savannah River Site, South Carolina, February 27, 1996. 

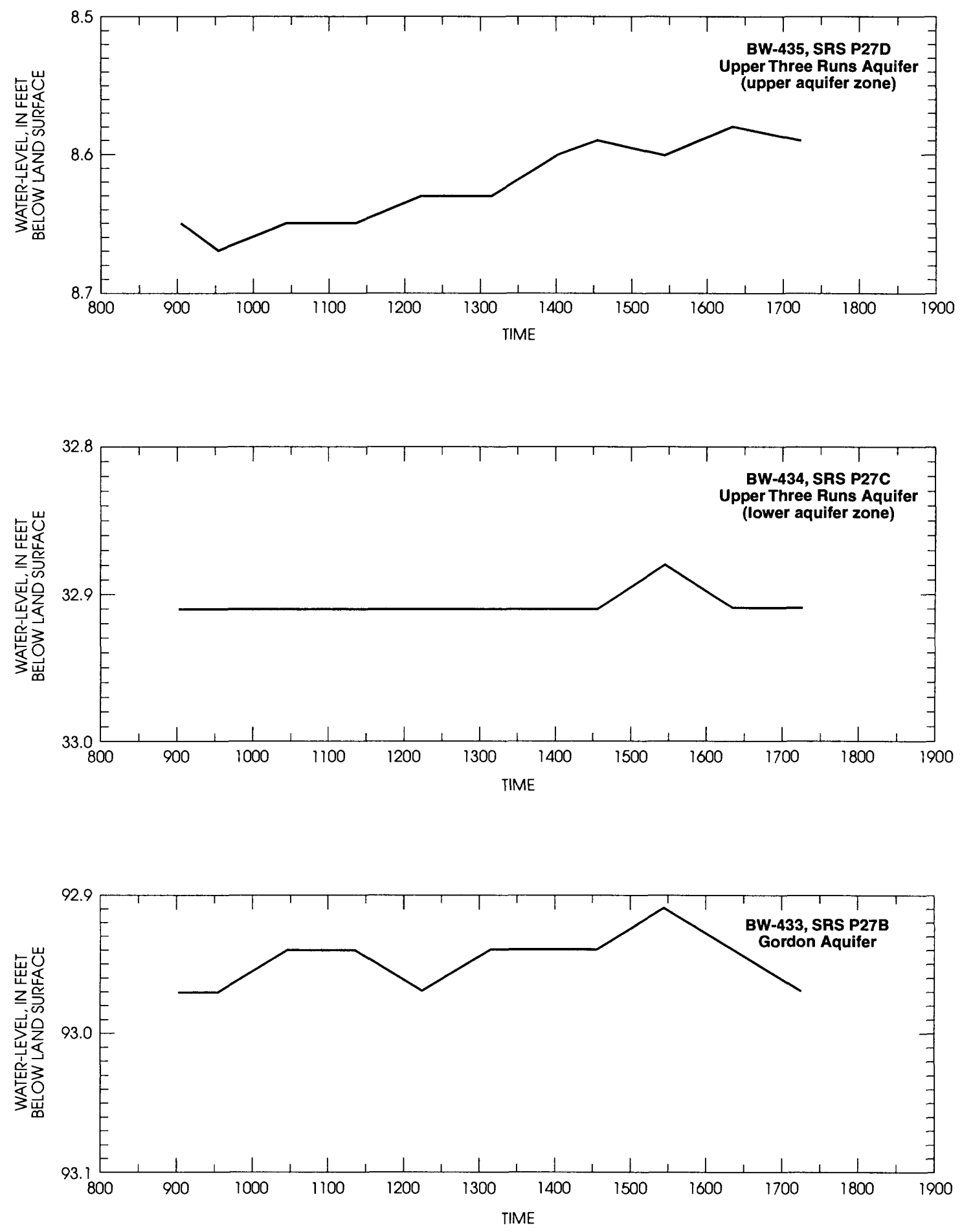

Figure 5. Water-level change in observation wells open to selected aquifers beneath the SRS P27 well cluster, in the General Separations Area, Savannah River Site, South Carolina, February 27, 1996. 


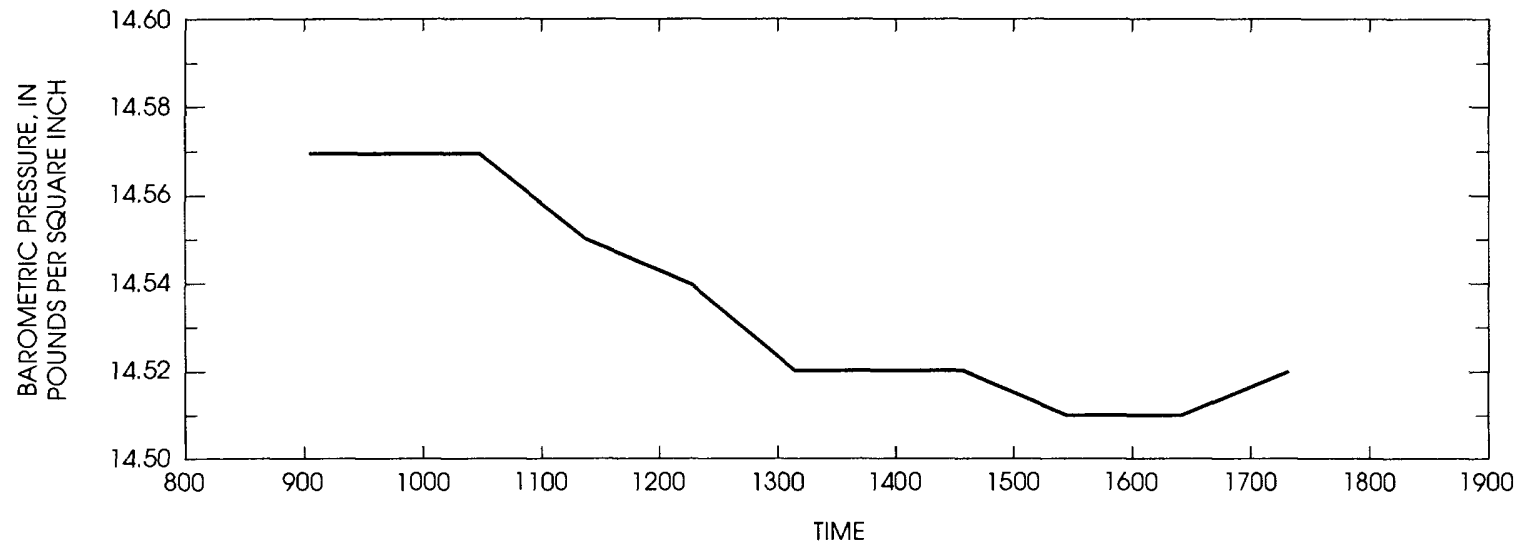

Figure 6. Barometric pressure change at well cluster SRS P27 in the General Separations Area, Savannah River Site, South Carolina, February 27, 1996.

\section{Gordon aquifer}

A total of 52 water-level measurements were collected from observation wells in the Gordon aquifer (table 3 at end of report). The Gordon aquifer is confined, except where the Gordon confining unit is breached by the incision of Upper Three Runs to the north and west of Area F. The configuration of the water-level surface (fig. 9) does not resemble local topography, as observed in both zones of the Upper Three Runs aquifer. The contours indicate a decline in head from an area south of Areas $Z$ and $Y$ to Upper Three Runs and indicate that some of the water in the Gordon aquifer arrives by lateral flow from areas to the east and northeast. The elevation of the water-level surface in the Gordon aquifer is lower than the waterlevel surface for the lower aquifer zone of the Upper Three Runs aquifer, with the exception of the unconfined part of the Gordon aquifer along Upper Three Runs. This suggests that the confined Gordon aquifer receives part of its recharge by leakage from the lower aquifer zone of the Upper Three Runs aquifer. 


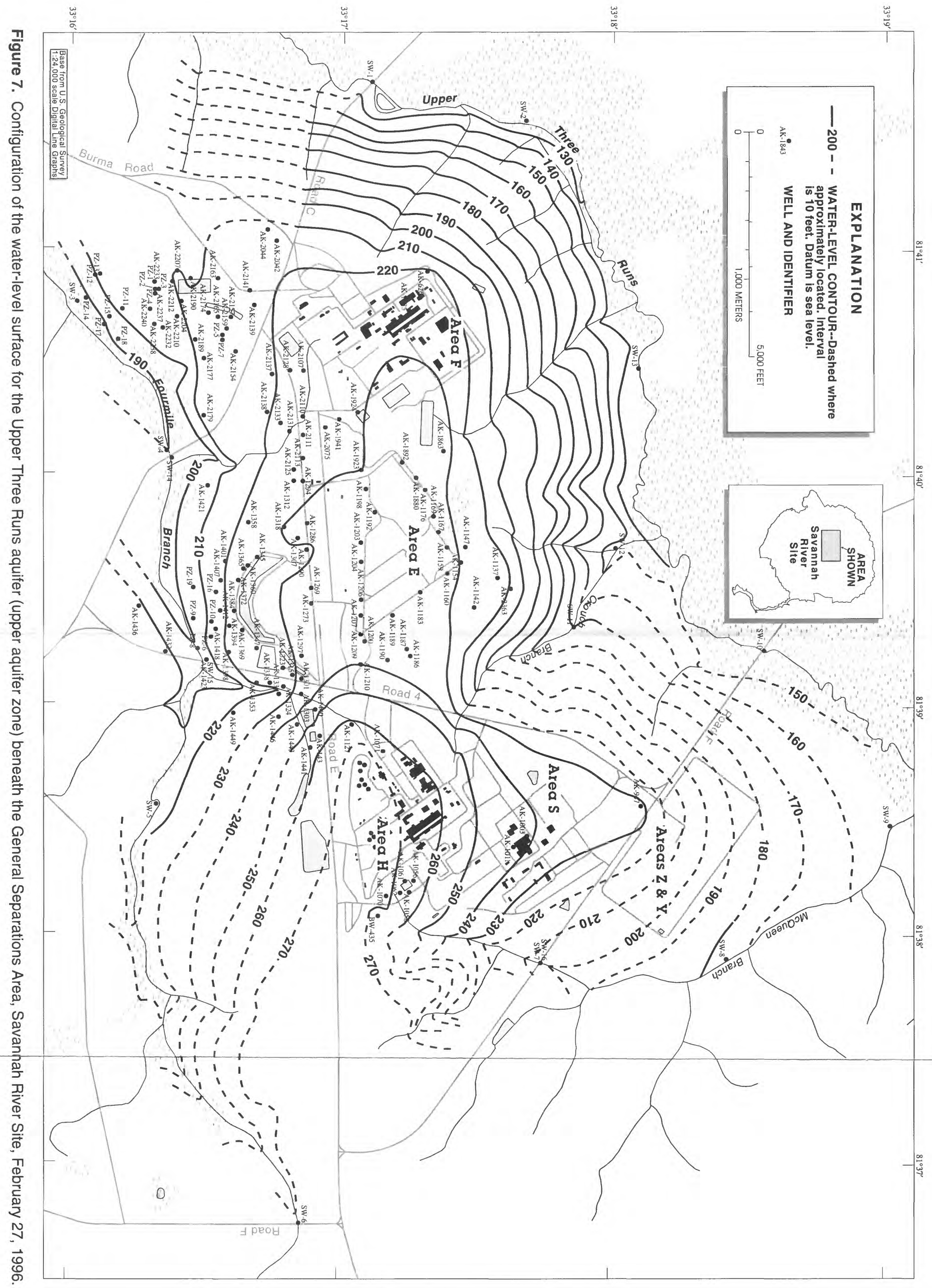




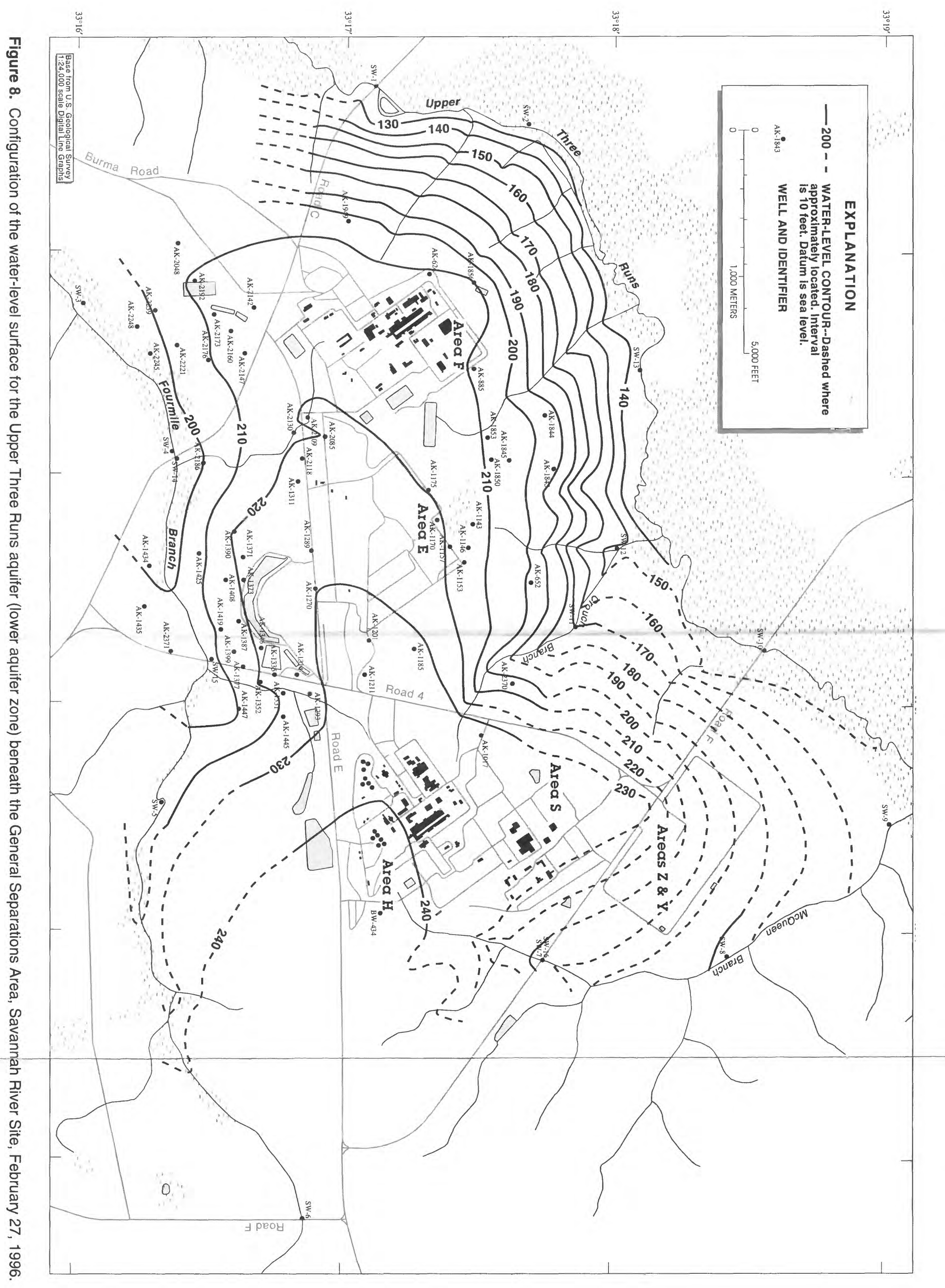




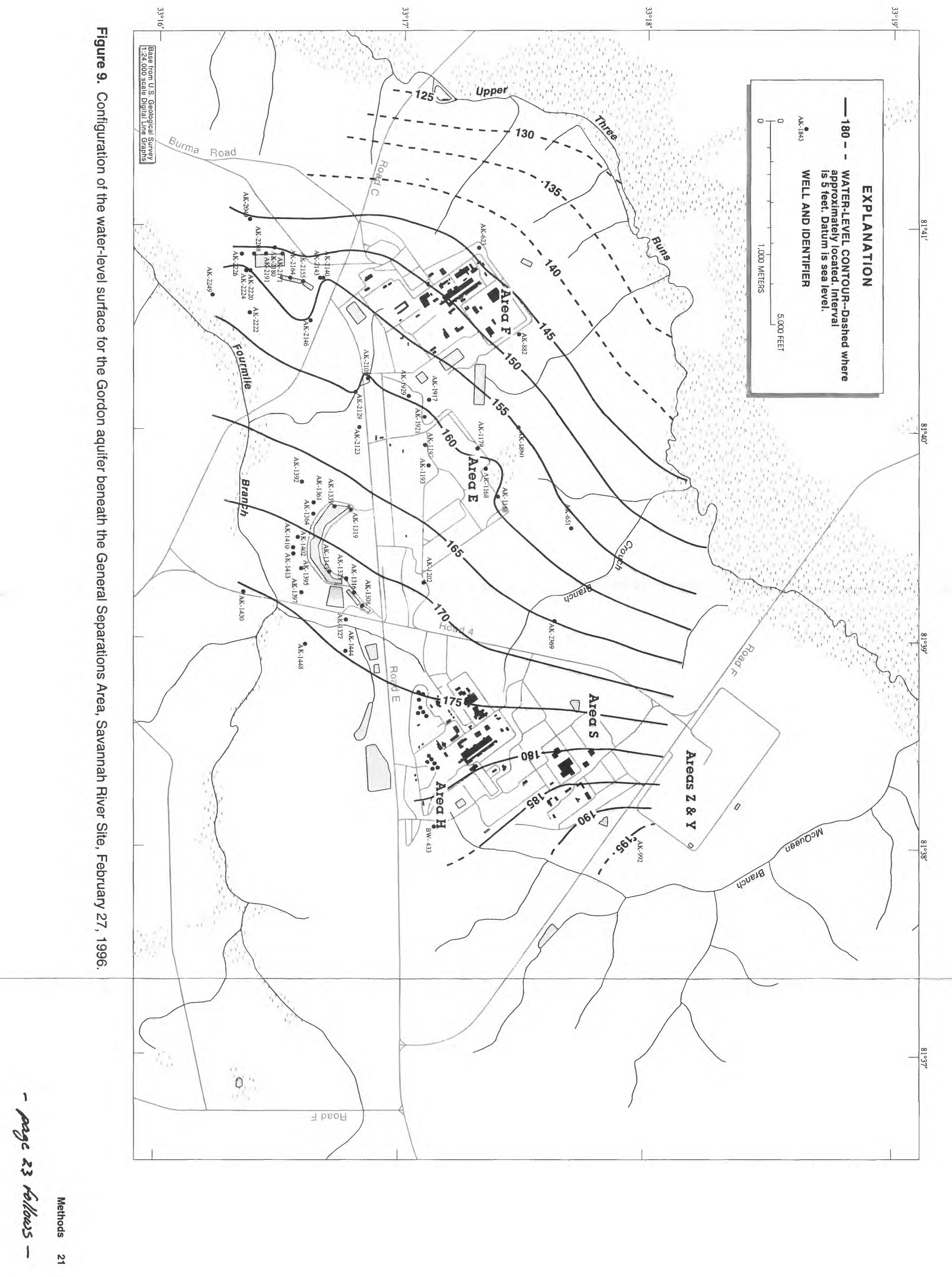




\section{SUMMARY}

This report presents the results of synoptic ground-water, surface-water, and barometric-pressure data collected on February 27, 1996. The study focused on the Upper Three Runs and Gordon aquifers beneath the GSA, SRS, South Carolina. The construction and activation of a pump-and-treat contaminant system, the placement of a clay cap over the Old Radioactive Burial Grounds, and the placement of a soil cover over the LLRWF and the MWMF could potentially change the shape of the water table and the potentiometric surfaces of these aquifer beneath the study area, and subsequently change the hydraulic gradients and the direction of ground-water flow in and around the sites of remedial activities.

The Tertiary age strata described in this report includes in ascending order the Lang Syne Formation, the Snapp Formation, the Fourmile Branch Formation, the Congaree Formation, the Warley Hill Formation, the Tinker Formation/Santee Limestone, the Clinchfield Formation, the Dry Branch Formation, the Tobacco Road Formation, and the "upland" unit.

The correlation of the geology and hydrogeology presented in this report provides the hydrogeologic framework required for the interpretation and description of the water-level surfaces of the upper and lower aquifer zones of the Upper Three Runs and the Gordon aquifers.

The Upper Three Runs aquifer includes all sediments from land surface down to the top of the Gordon confining unit. In the vicinity of the GSA, the Upper Three Runs aquifer is correlative to the "upland" unit, the Tobacco Road Formation, Dry Branch Formation, Clinchfield Formation, and most of the Tinker Formation/Santee Limestone. The Upper Three Runs aquifer is divided into the upper and lower aquifer zones, that are separated by the "tan clay" confining zone.

The Gordon confining unit includes all sediments from the lower most clay beds of the Tinker Formation/Santee Limestone to the upper most clay beds of the Congaree Formation. The Gordon confining unit is the equivalent of the "green clay" confining unit of the Congaree Formation, the Warley Hill Formation, and the Tinker Formation/Santee Limestone.

The Gordon aquifer includes all sediments from the top of the Snapp Formation to the upper most clay beds of the Congaree Formation, depending on the thickness and stratigraphic distribution of the "green clay" lithology near the contact of the Congaree and the Warley Hill Formations. The base of the Gordon aqui- fer is defined by the top of the clay lithologies of either the Snapp Formation or, in the absence of the clays of the Snapp Formation, the Lang Syne Formation. The Meyers Branch confining system includes all sediments of the Lang Syne and Snapp Formations.

Synoptic ground- and surface-water and barometric-pressure data were collected to map the waterlevel surfaces of the upper and lower aquifer zones of the Upper Three Runs and Gordon aquifers in the GSA. During 9 hours on February 27, 1996, water levels were collected from 231 wells, 19 piezometers, and 16 surface-water sites. Barometric pressure was monitored. Barometric pressure during the measurement period varied $0.06 \mathrm{lb} / \mathrm{in}^{2}$. Changes in water levels in the monitored wells at the SRS P27 well cluster was 0.06 and $0.09 \mathrm{ft}$. No significant change in the water levels from the barometric pressure was observed during the data measurement period.

The upper aquifer zone of the Upper Three Runs aquifer is unconfined and the lower aquifer zone of the aquifer is unconfined, semi-confined, or confined. Water levels in the upper aquifer zone are higher than the lower aquifer zone across the crest of the GSA interfluve and suggest that the semi-confined and confined parts of the lower aquifer zone in this area receive recharge by leakage from the upper aquifer zone. Two ground-water divides trending approximately eastwest and north-south are prominent features of the water table in the upper aquifer zone. The east-west trending divide is also observed in the potentiometric surface for the lower aquifer zone. The configuration of the water-level surfaces resemble local topography, and the divides on both maps roughly coincide with the topographically high areas of the interfluve. Both aquifer zones discharge to McQueen Branch, Crouch Branch, and the other tributaries to the Upper Three Runs and Fourmile Branch on the flanks of the GSA interfluve.

The Gordon aquifer receives recharge from lateral flow from areas to the east and northeast of the GSA and leakage from the lower aquifer zone of the Upper Three Runs aquifer. The Gordon aquifer is confined beneath all of the GSA interfluve, except where the Gordon confining unit is breached by the incision of Upper Three Runs to the north and west of Area F. The potentiometric surface of the Gordon aquifer does not resemble the local topography. 


\section{REFERENCES}

Aadland, R.K., and Bledsoe, H.W., 1990, Classification of Hydrostratigraphic Units at the Savannah River Site, South Carolina (U): USDOE Report WSRC-RP-90987, Westinghouse Savannah River Company, 15 p.

Aadland, R.K., Harris M.K., Lewis, C.M., Gaughan, T.F., and Westbrook, T.F., 1991, Hydrostratigraphy of the General Separations Area, Savannah River Site (SRS), South Carolina: USDOE Report WSRC-RP-91-13, Westinghouse Savannah River Company, 114 p.

Aadland, R.K., Smits, A.D., and Thayer, P.A., 1992, Geology and Hydrostratigraphy of the A/M Area, Savannah River Site (SRS), South Carolina (U): USDOE Report WSRC-RP-92-440, Westinghouse Savannah River Company, Savannah River Site, 104 p.

Aadland, R.K., Gellici, J.A., and Thayer, P.A., 1995, Hydrogeologic framework of west-central South Carolina: South Carolina Department of Natural Resources, Water Resources Division Report 5, 200 p.

Bechtel Corporation, 1982, Studies of Postulated Millett fault: unpublished report on file at the U.S. Geological Survey, Atlanta, Georgia [variously paged].

Bledsoe, H.W., Aadland, R.K., and Sargent, K.A., 1990, SRS baseline hydrogeologic investigation - Summary Report: U.S. DOE Report, WSRC-RP-90-1010, Westinghouse Savannah River Co., Savannah River Laboratory, $40 \mathrm{p}$.

Buss, D.R., Duffield, G.M., Wadsworth, T.S., and Mercer, J.W., 1987, Characterization of groundwater flow in the General Separations Areas, Savannah River Plant: Evaluation of a corrective groundwater action for the $F$ and $\mathrm{H}$ Areas seepage basins, Geotrans, Inc., Consulting Report for E. I. du Pont de Nemours and Company, Environmental Sciences Division, Savannah River Laboratory, Aiken S.C. [variously paged].

Christl, R.J., 1964, Storage of radioactive wastes in basement rock beneath the Savannah River Plant: E. I. du Pont de Nemours and Co., Report DP-844, 105 p.

Colquhoun, D.J., and Johnson, H.S., Jr., 1968, Tertiary sealevel fluctuation in South Carolina: Paleogeography, Paleoclimatology, Paleoecology, v.5, p.105-126.

Colquhoun, D.J., Oldham, R.W., Bishop, J.W., and Howell, P. D., 1982, Updip delineation of the Tertiary limestone aquifer, South Carolina: Clemson, South Carolina, Clemson University Water-Resources Research Institute, Report no. 97,93 p.

Colquhoun, D.J., Woollen, I.D., Van Nieuwenhuise, D.S., Padgett, G.G., Oldham, R.W., Boylan, D.C., Bishop, J.W., and Howell, P.D., 1983, Surface and subsurface stratigraphy, structure and aquifers of the South Carolina Coastal Plain: South Carolina Department of Health and Environmental Control, Governor's Office, and University of South Carolina, Columbia, South Carolina, 78 p.
Colquhoun, D.J., and Muthig, M.G., 1991, Stratigraphy and structure of the Paleocene and lower Eocene Black Mingo Group, in Horton, J.W., Jr., and Zullo, V.A., eds., Geology of the Carolinas: University of Tennessee Press, Knoxville, Tennessee, p. 241-250.

Colquhoun, D.J., Rine, J.M., Segall, M.P., Katuna, M.P., Cohen, A.D., and Sivon, D.L., 1994, Sedimentology and stratigraphy of the Upland unit: Final Report under SCUREF cooperative agreement with DOE, Task 119 AA00900T to DOE, Geological Sciences Department Earth Sciences and Resources Institute, University of South Carolina, Columbia, S.C.

Cook, J.R., 1986, Hydrologic data from Z Area: E. I. du Pont de Nemours and Co., Savannah River Laboratory, DPST-86-320, $113 \mathrm{p}$.

Cooke, C.W., 1936, Geology of the Coastal Plain of South Carolina: U. S. Geological Survey Bulletin 867, 196 p.

Cooke, C.W., and MacNeil, F.S., 1952, Tertiary stratigraphy of South Carolina: U.S. Geological Survey Professional Paper 243-B, p. 19-29.

D'Appolonia, 1981, Boring and instrument installation, DWFP salt disposal site, E. I. du Pont Nemours and Co., Savannah River Laboratory, Aiken, S.C., 37 p. 1982, Preliminary Safety Analysis-Defense Waste Processing Facility, Volumes 1- 4: E. I. du Pont de Nemours and Company, Savannah River Laboratory, DPST-82-675.

Daniels, D.L., 1974, Geologic interpretation of geophysical maps, central Savannah River area, South Carolina and Georgia: U.S. Geological Survey Geophysical Investigations Map GP-893, 3 sheets.

Dennehy, K.F., Prowell, D.C., and McMahon, P.B., 1989, Reconnaissance hydrogeologic investigation of the Defense Waste Processing Facility and Vicinity, Savannah River Plant, South Carolina: U.S. Geological Survey Water-Resources Investigations Report 88-4221, $68 \mathrm{p}$.

Duffield, G.M., Buss, D.R., Spalding, C.P., and Plante, L.A., 1987, Characterization of groundwater flow and transport in the General Separations Area, Savannah River Plant: Effect of closure cap on Solute Transport Mixed Waste Management Facility (643-28G), Geotrans, Inc., Phase II Consulting Report for E. I. du Pont de Nemours and Company, Waste Management Projects, Savannah River Plant, Aiken, S.C., 132 p.

Fallaw, W.C., Price, Van, and Thayer, P.A., 1989, Cretaceous deltaic facies in southwestern Coastal Plain of South Carolina: American Association of Petroleum Geologist Bulletin, v. 73, p. 354 
Fallaw, W.C., and Price, Van, 1992, Outline of stratigraphy at the Savannah River Site: in Fallaw, W. C., and Price, Van, eds., 1992, Carolina Geological Society Field Trip Guide Book, Nov. 13-15, 1992, Geological investigations of the central Savannah River area, South Carolina and Georgia: U.S. Department of Energy and South Carolina Geological Survey, p. SCGS-92-B-11-1-33. 1995, Stratigraphy of the Savannah River Site and vicinity: Southeastern Geology, v. 35, no. 1, p. 21-58.

Fallaw, W.C., Price, Van., and Sexton, W.J., 1992, Outcrops in the vicinity of the Savannah River Site, in Fallaw, W. C., and Price, Van., eds., 1992, Carolina Geological Society field trip guidebook, November 13-15, 1992, Geological investigations of the central Savannah River area, South Carolina and Georgia: U. S. Department of Energy and South Carolina Geological Survey, p. CGS92-A-1-14.

Fallaw, W.C., Price, Van., and Thayer, P.A., 1992a, Cretaceous lithofacies at the Savannah River Site, South Carolina, in Zullo, V.A., Harris, W.B., and Price, V., eds., Savannah River region: Transition between the Gulf and Atlantic Coastal Plains, Proceedings of the second Bald Head Island Conference on Coastal Plains Geology: University of North Carolina at Wilmington and U.S. Department of Energy, p. 50-51.

1992b, Stratigraphy of the Savannah River Site, South Carolina, in Zullo, V.A., Harris, W.B., and Price, V., eds., Savannah River region: transition between the Gulf and Atlantic coastal plains, proceedings of the second Bald Head Island Conference on Coastal Plains Geology: University of North Carolina at Wilmington and U.S. Department of Energy, p. 29-32.

Fallaw, W.C., Snipes, D.S., Daggett, J.S., Furlow, L., James, A., Moore, J.P., Price, S., and Price, V., 1992, Stratigraphic relationships in Eocene outcrops along Upper Three Runs at the Savannah River Site, in Fallaw, W.C., and Price, V., eds., 1992, Carolina Geological Society field trip guidebook, November 13-15, 1992, Geological investigations of the central Savannah River area, South Carolina and Georgia: U.S. Department of Energy and South Carolina Geological Survey, p. CGS-92-B-III-1-3.

Faye, R.E., and Prowell, D. C., 1982, Effects of Late Cretaceous and Cenozoic faulting on the geology and hydrology of the Coastal Plain near the Savannah River, Georgia and South Carolina: U.S. Geological Survey Open File Report 82-156, 85 p.

Ferris, J. G., Knowles, D. B., Brown, R. H., and Stallman, R. W., 1962, Theory of aquifer test: U.S. Geological Survey Water-Supply Paper 1536-E, p. 78-91.

Geotrans, Inc., 1988a, Characterization of groundwater flow and transport in the General Separations Area Savannah River Plant: Effects of closure options on groundwater flow F-Area seepage basins, Phase I Consulting Report for E. I. du Pont de Numours and Company, Environ- mental Sciences Division and Waste Management Technology Division, Savannah River Laboratory, Aiken S.C., 30 p.

Geotrans, Inc., 1988b, Characterization of groundwater flow and transport in the General Separations Area Savannah River Plant: Effect of closure options on groundwater flow H-Area seepage basins, Phase I Consulting Report for E. I. du Pont de Numours and Company, Environmental Sciences Division and Waste Management Technology Division, Savannah River Laboratory, Aiken S.C., 52 p.

Geotrans, Inc., 1988c, Characterization of groundwater flow and transport in the General Separations Area Savannah River Plant: Effects of closure options on Solute Transport F-Area seepage basins, Consulting Report for E. I. du Pont de Numours and Company, Environmental Sciences Division and Waste Management Technology Division, Savannah River Laboratory, Aiken S.C., $121 \mathrm{p}$.

Geotrans, Inc., 1988d, Characterization of groundwater flow and transport in the General Separations Area Savannah River Plant: Effect of closure options on Solute Transport H-Area seepage basins, Consulting Report for E. I. du Pont de Nemours and Company, Environmental Sciences Division and Waste Management Technology Division, Savannah River Laboratory, Aiken S.C., $125 \mathrm{p}$.

Gohn, G.S., Hazel, J.E., Bybell, L.M., and Edwards, L.E., 1983, The Fishburne Formation (lower Eocene), a newly defined subsurface unit in the South Carolina Coastal Plain: U.S. Geological Survey Bulletin 1537-C, $16 \mathrm{p}$.

Harrelson, L.G., Falls, W.F., and Clarke, J.S., 1997, Selected well data in the vicinity of the Savannah River Site, South Carolina and Georgia: U.S. Geological Survey, Open-File Report 96-657-A, 215 p.

Harris, M.K., Aadland, R.K., and Westbrook, T.M., 1992, Lithological and hydrological characteristics of the Tertiary Hydrostratigraphic Systems of the General Separations Area, Savannah River Site, South Carolina: in Zullo, V.A., Harris, W.B., and Price, V., eds., 1992, Savannah River Region, Transition between the Gulf and Atlantic Coastal Plains, Proceedings of the Second Bald Head Island Conference on Coastal Plains Geology, University of North Carolina at Wilmington, Wilmington, N.C., p. 68-73.

Harris, W.B., Zullo, V.A. and Laws, R.A., 1993, Sequence stratigraphy of the onshore Paleogene, southeastern Atlantic Coastal Plain, USA: in Posamentier, H.W., Summerhayes, C.P., Haq, B.U., and Allen, G.P., eds., Sequence Stratigraphy and Facies Associations, Blackwell, Oxford, International Association of Sedimentologists Special Publication 18, p. 537-561. 
Howell, P.D., 1985, Surface and subsurface lithostratigraphy and depositional history of the Upper Cretaceous, Paleocene, and middle Eocene strata of the Coastal Plain of updip central South Carolina: University of South Carolina, Columbia, S.C., unpublished M.S. thesis, $118 \mathrm{p}$.

Huddlestun, P.F, 1982, The development of the stratigraphic terminology of the Lutetian and Jacksonian/Priabonian marine deposits of western South Carolina and eastern Georgia, in Nystrom, P.G., Jr., and Willoughby, R.H., eds., Geological Investigations Related to the Stratigraphy in the Kaolin Mining District, Aiken County, South Carolina: South Carolina State Development Board, Division of Geology, Columbia, S.C., Carolina Geological Society Field Trip Guidebook 1982, p. 21-33.

Huddlestun, P.F., and Hetrick, J.H., 1979, The stratigraphy of the Barnwell group in Georgia: Georgia Geologic Survey Open-File Report 80-1, published for the 14th field trip of the Georgia Geologic Survey Bulletin 93, p. 56-73.

1985, Upper Eocene stratigraphy of central and eastern Georgia: Georgia Geologic Survey Bulletin 95, $78 \mathrm{p}$.

1988, A revision of the lithostratigraphic units of the Coastal Plain of Georgia, the Miocene through Holocene: Georgia Geologic Survey Bulletin 104, $162 \mathrm{p}$.

Laws, R.A., Harris, W.B., and Zullo, V.A., 1992, Nannofossil biostratigraphy and sequence stratigraphy of middle to upper Eocene strata in the southwestern Savannah River Site and adjacent areas of Georgia, in Fallaw, W.C., and Price, Van, eds., Geological Investigations of the Central Savannah River Area, South Carolina and Georgia: Carolina Geological Society Field Trip Guidebook 1992, South Carolina State Development Board, Division of Geology, Columbia, S.C., p. B.VII.1 B.VII.4.

Logan, W.R., and Euler, G.M., 1989, Geology and groundwater resources of Allendale, Bamberg, and Barnwell Counties and part of Aiken County, South Carolina: South Carolina Water Resources Commission Report, 155, $113 \mathrm{p}$.

Lyell, C., 1845, Observations on the white limestone and other Eocene or older Tertiary formations of Virginia, South Carolina, and Georgia: Quarterly Journal of the Geological Society of London, 1, p. 429-442.

Marine, I.W., 1979, Hydrology of buried crystalline rocks at the Savannah River Plant near Aiken, South Carolina: U.S. Geological Survey Open-File Report 79-1544, $160 \mathrm{p}$.

Marine, I.W., and Root, R.W., Jr., 1978, Geohydrology of deposits of Claiborne age at the Savannah River Laboratory Environmental Transport and Effects Research Annual Report DP-1489, p. 57-60.
McClelland, S.A., 1987, Surface and subsurface stratigraphy of Cretaceous and younger strata along the Savannah River from Southern Richmond County through Burke County, Georgia: Department of Geology, University of South Carolina, Columbia, S.C., Masters thesis, $123 \mathrm{p}$.

Muthig, M.G., and Colquhoun, D.J., 1988, Formal recognition of two members within the Rhems Formation in Calhoun County, South Carolina: South Carolina Geology, v. 32, p. 11-19.

Nystrom, P.G., Jr., 1986, Cretaceous-Tertiary stratigraphy of the updip limit of the Coastal Plain between Ward and Leesville, South Carolina: Geological Society of America Abstracts with Programs, 18, $258 \mathrm{p}$.

Nystrom, P.G., Jr. and Willoughby, R.H., 1982, Cretaceous, Tertiary, and Pleistocene(?) stratigraphy of Hollow Creek and Graniteville quadrangles, Aiken County, South Carolina, in Nystrom, P.G., Jr., and Willoughby, R.H., eds., Geological Investigations Related to the Stratigraphy in the Kaolin Mining District, Aiken County, South Carolina: Carolina Geological Society Field Trip Guidebook 1982, South Carolina State Development Board, Division of Geology, Columbia, S.C., p. 80-113.

1992, The upland unit in the Savannah River Site: distribution, lithology, depositional environment, and age: Geological Society of America 1992 Abstracts with Programs, v. 24, no. 2, p.56.

Nystrom, P.G., Jr., Willoughby, R.H., and Price, L.K., 198 The Cretaceous and Tertiary stratigraphy of the upper Coastal Plain of South Carolina, in Upper Cretaceous and Cenozoic geology of the southeastern Atlantic Coastal Plain: International Geological Congress, 28th, Field Trip Guidebook T172, p. 23-42.

-1991 , Cretaceous and Tertiary stratigraphy of the upper Coastal Plain of South Carolina, in The Geology of the Carolinas, Horton, J.W., and Zullo, V.A., eds.: University of Tennessee Press, Knoxville, Tenn., p. 221-241.

Padgett, G.G., 1980, Lithostratigraphy of the Black Mingo Formation in Sumter, Calhoun, and Richland Counties, South Carolina: University of South Carolina, Columbia, S.C., unpublished M.S. thesis, 68 p.

Parizek, R.R., and Root, R.W., Jr., 1984, Progress toward the development of a ground-water velocity model for the Radioactive Waste Management Facility Savannah River Plant, South Carolina, Quarterly Report, July 15, 1984: The Pennsylvania State University.

Pooser, W.K., 1965, Biostratigraphy of Cenozoic Ostracoda from South Carolina: University of Kansas Paleontological Contributions, Arthropoda, Article 8, $80 \mathrm{p}$.

Price, V., Fallaw, W.C., and Thayer, P.A., 1992, Lower Eocene strata at the Savannah River Site, South Carolina, in Zullo, V. A., Harris, W. B., and Price, V., eds., Savannah River region: Transition between the Gulf 
and Atlantic coastal plains, proceedings of the second Bald Head Island Conference on Coastal Plains Geology: University of North Carolina at Wilmington and U.S. Department of Energy, p. 52-53.

Prowell, D.C., 1994, Preliminary Geologic Map of the Savannah River Site, Aiken, Allendale, and Barnwell Counties, South Carolina: U.S. Geological Open-File Report 94-181, 15 p.

Prowell, D.C., Christopher, R.A., Edwards, L.E., Bybell, L.M., and Gill, H.E., 1985, Geologic section of the updip Coastal Plain from central Georgia to western South Carolina: U. S. Geological Survey Miscellaneous Field Studies Map MF-1737, 11 p.

Prowell, D.C., Edwards, L.E., and Frederiksen, N.O., 1985, The Ellenton Formation in South Carolina - a revised age designation from Cretaceous to Paleocene: U.S. Geological Survey Bulletin 1605-A, p. A63-A69.

Robertson, C.G., 1990, A textural, petrographic, and hydrogeological study of the Congaree Formation at the Savannah River Site, South Carolina: M.S. thesis, University of North Carolina at Wilmington, Wilmington, N.C., $65 \mathrm{p}$.

Robertson, C.G., and Thayer, P.A., 1992, Petrology and reservoir characteristics of the Congaree Formation at the Savannah River Site, South Carolina, in Zullo, V.A., Harris, W.B., and Price, V., eds., Savannah River Region, Transition between the Gulf and Atlantic Coastal Plains, Proceedings of the Second Bald Head Island Conference on Coastal Plains Geology: University of North Carolina at Wilmington and U.S. Department of Energy, Wilmington, N.C., p. 54-55.

Root, R.W., Jr., 1980, Ground-water data from the H-Area, Savannah River Plant, South Carolina: Savannah River Laboratory Report DPST-80-601, 34 p.

1981, Results of drilling a well cluster near F-Area at SRP: Savannah River Laboratory Report DPST-81503.

Sargent, K.A., 1984, Study of a perched condition in the DWPF saltstone disposal site: E. I. du Pont de Nemours and Company, Savannah River Laboratory, Aiken, S.C., $113 \mathrm{p}$.

Siple, G.E., 1967, Geology and ground water of the Savannah River plant and vicinity, South Carolina: U.S. Geological Survey Water Supply Paper 1841, 113 p.

Sloan, E., 1908, Catalogue of the mineral localities of South Carolina: South Carolina Geological Survey, Series 4, Bulletin 2, 505 p.

Smith, G.W., III, 1979, Lithostratigraphic relationships of Coastal Plain units in Lexington County and adjacent area, South Carolina: University of South Carolina, Department of Geology, Columbia, S.C., M.S. thesis, $139 \mathrm{p}$.

Snipes, D.S., Fallaw, W.C., and Price, V., Jr., 1992, Structural geology of the Savannah River Site in the Coastal Plain of South Carolina, in Zullo, V.A., Harris, W.B., and Price, V., eds., Savannah River Region, Transition between the Gulf and Atlantic Coastal Plains, Proceedings of the Second Bald Head Island Conference on Coastal Plains Geology: University of North Carolina at Wilmington and U.S. Department of Energy, Wilmington, N.C., p. 33-36.

Snipes, D.S., Fallaw, W.C., Price, V., Jr., and Combust, R.J., 1993, The Pen Branch fault-documentation of Late Cretaceous-Tertiary faulting in the Coastal Plain of South Carolina: Southeastern Geology, v. 33, p. 195218.

Spalding, C.P., Duffield, G.M., Buss, D.R., and Plante, L.A., 1987, Characterization of Groundwater Flow and Transport in the General Separations Area, Savannah River Site: Effect of closure cap on Tritium Migration Mixed Waste Management Facility (643-28G): Geo Trans, Inc., Phase II Consulting Report for E. I. du Pont de Nemours and Company (draft), Waste Management Projects, Savannah River Plant, Aiken S.C. [variously paged].

Steele, K.B., 1985, Lithostratigraphic correlation of Cretaceous and younger strata of the Atlantic Coastal Plain Province within Aiken, Allendale, and Barnwell Counties, South Carolina: Department of Geology, University of South Carolina, Columbia, S.C., M.S. thesis, $174 \mathrm{p}$.

1992, Evidence of structural control on stratigraphic horizons in Aiken County, S.C.: Geological Society of America 1992, Abstracts with Programs, v. 24, no. 2, $65 \mathrm{p}$.

Thayer, P.A. and Harris, M. K., 1992, Petrology and reservoir characteristics of middle and late Eocene carbonate strata in downdip wells at the Savannah River Site, S.C., in Fallaw, W.C., and Price, V., eds., Geological Investigations of the Central Savannah River Area, South Carolina and Georgia, Carolina Geological Society Field Trip Guidebook 1992: U.S. Department of Energy and South Carolina State Development Board, Division of Geology, Columbia, S.C., p. B.V.1-B.V.7.

Thayer, P.A., Smits, A. D., Harris, M. K., Lewis, C. M., and Amidon, M. B., 1993, Hydrostratigraphic maps of the General Separations Area (GSA), Savannah River Site (SRS), Aiken, South Carolina, Phase II (U): U. S. Department of Energy Report WSRC-RP-94-40, Westinghouse Savannah River Company, Aiken, S.C., $86 \mathrm{p}$.

Thayer, P.A., Smits, A. D., Parker, W. H., Conner, K. R., Harris, M. K., and Amidon, M. B., 1993, Petrographic analysis of mixed carbonate-clastic hydrostratigraphic units in the General Separations Area (GSA), Savannah River Site (SRS), Aiken, South Carolina (U): U. S. Department of Energy Report WSRC-RP-94-54, Westinghouse Savannah River Company, Aiken, S.C., 83 p. 
Westinghouse Savannah River Company, 1992, Section E.2: General hydrogeologic information, in RCRA Part B Permit Application, Savannah River Site, Volume VII, Mixed Waste Management Facility (MWMF) post closure, WSRC-IM-91-53: Westinghouse Savannah River Company, p. E11-E206.

1995, Environmental Protection Department's well inventory (U): Westinghouse Savannah River Company, Aiken, S.C., ESH-EMS-950419, Prepared for U.S. Department of Energy contract no. AA89128P, $243 \mathrm{p}$.

Willoughby, R. H., 1983, Geologic map of the Graniteville quadrangle: South Carolina Geological Survey OpenFile Report 31, scale 1:24,000.

1985, Geologic map of the Coastal Plain in Johnston and Edgefield quadrangle: South Carolina Geological Survey Open-File Report 46, scale 1:24,000.

1986, Stratigraphy of the northwestern edge of the Coastal Plain in Aiken and Lexington counties, South Carolina: Geological Society of America, Abstracts with Programs, v. 18, no. 3, p. 272-273. 
TABLES 1-7

- page 31 follows - 
[Blank Page]

30 Ground-Water Levels in the Upper Three Runs and Gordon Aquifers in the General Separations Area, Savannah River Site, South Carolina, 1996 


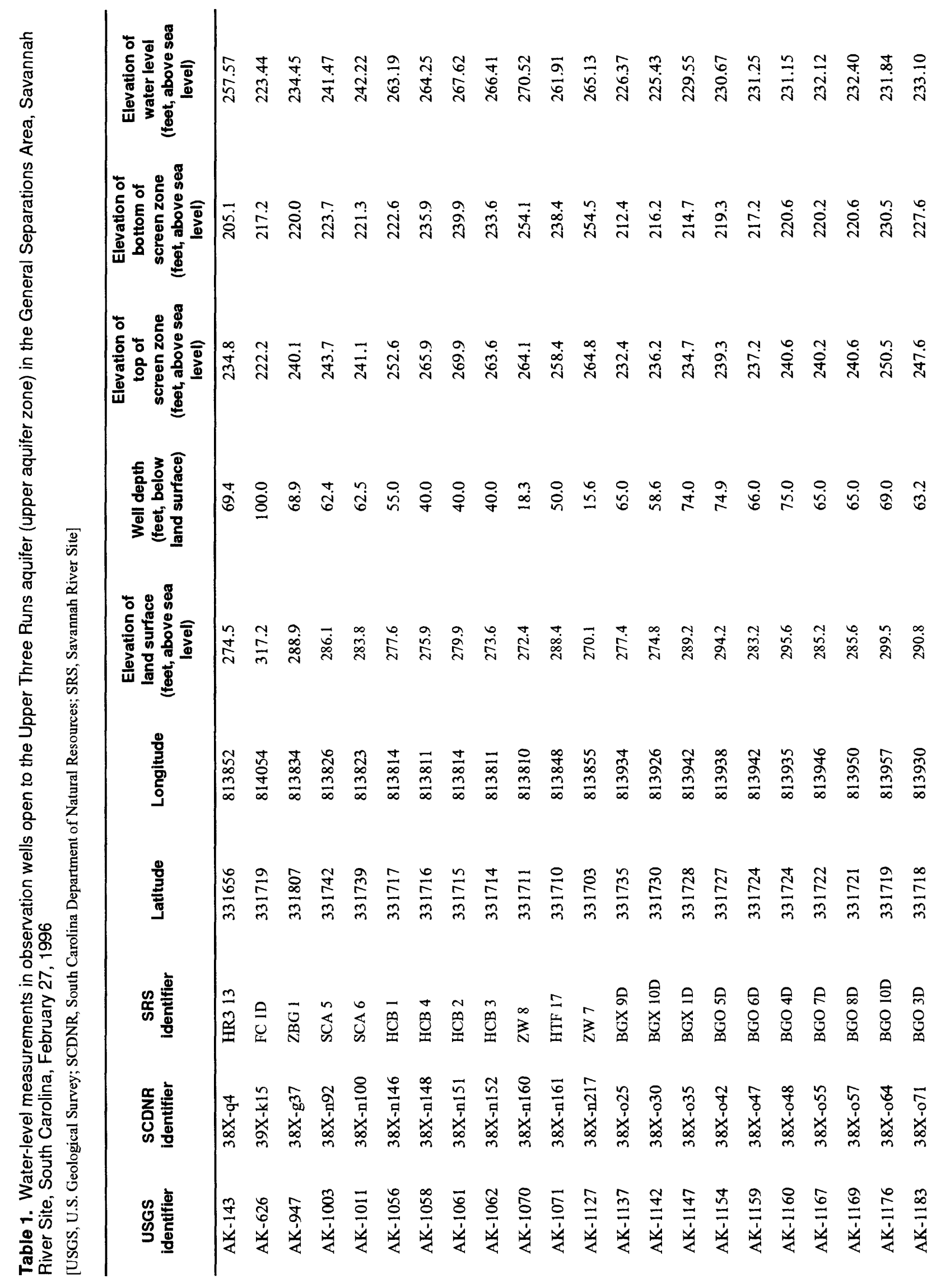




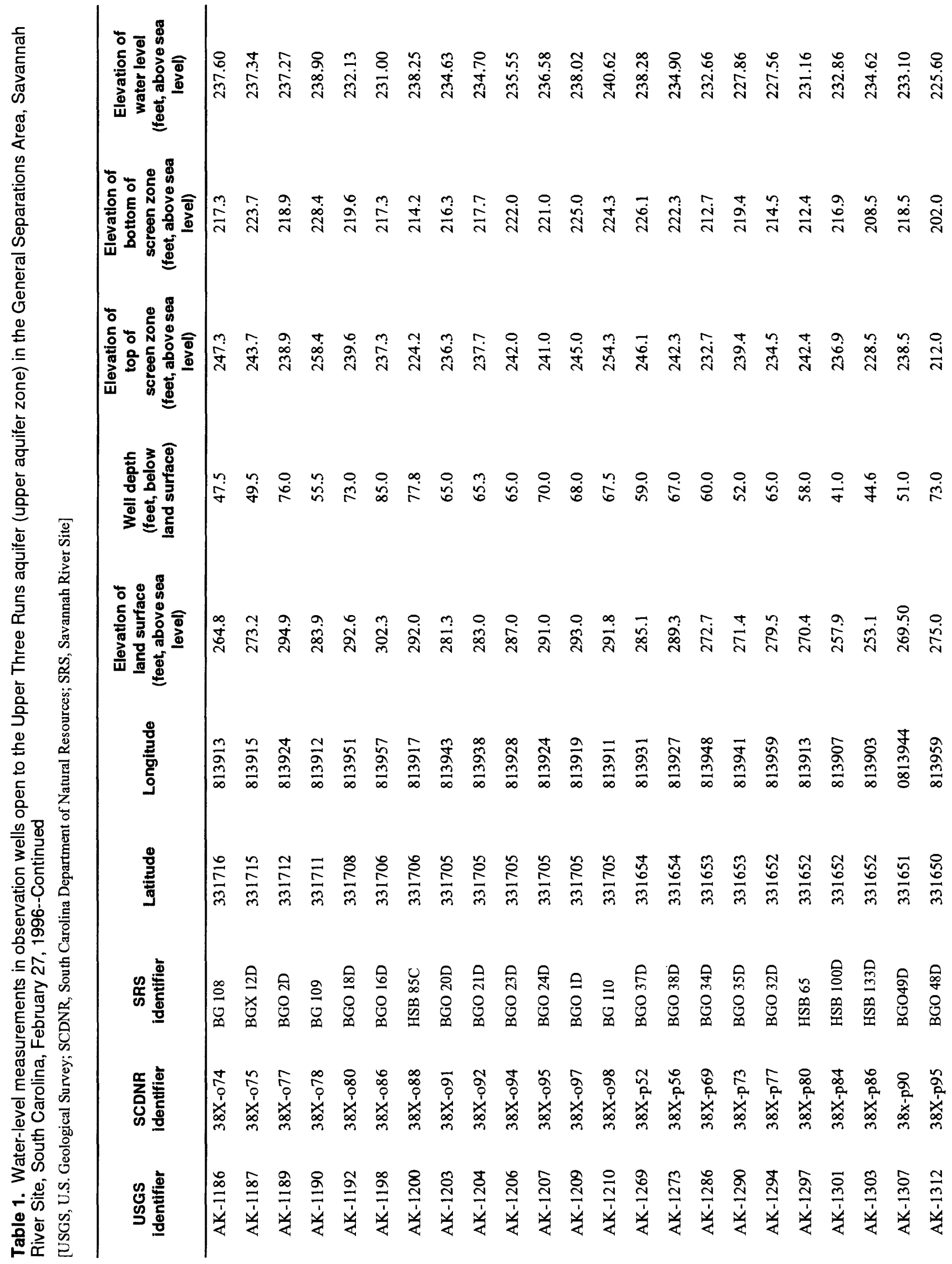

32 Ground-Water Levels in the Upper Three Runs and Gordon Aquifers in the General Separations Area, Savannah River Site, South Carolina, 1996 


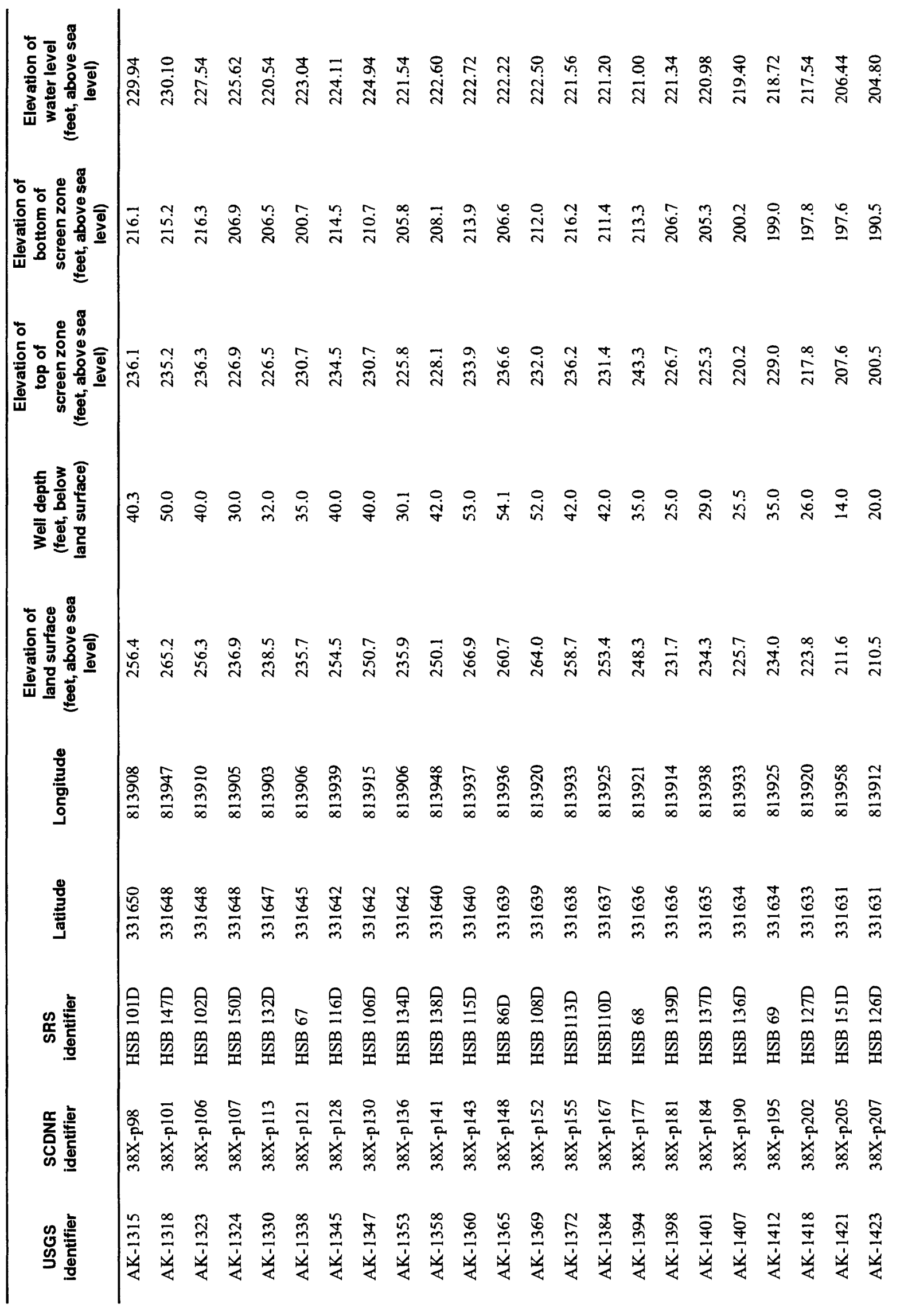




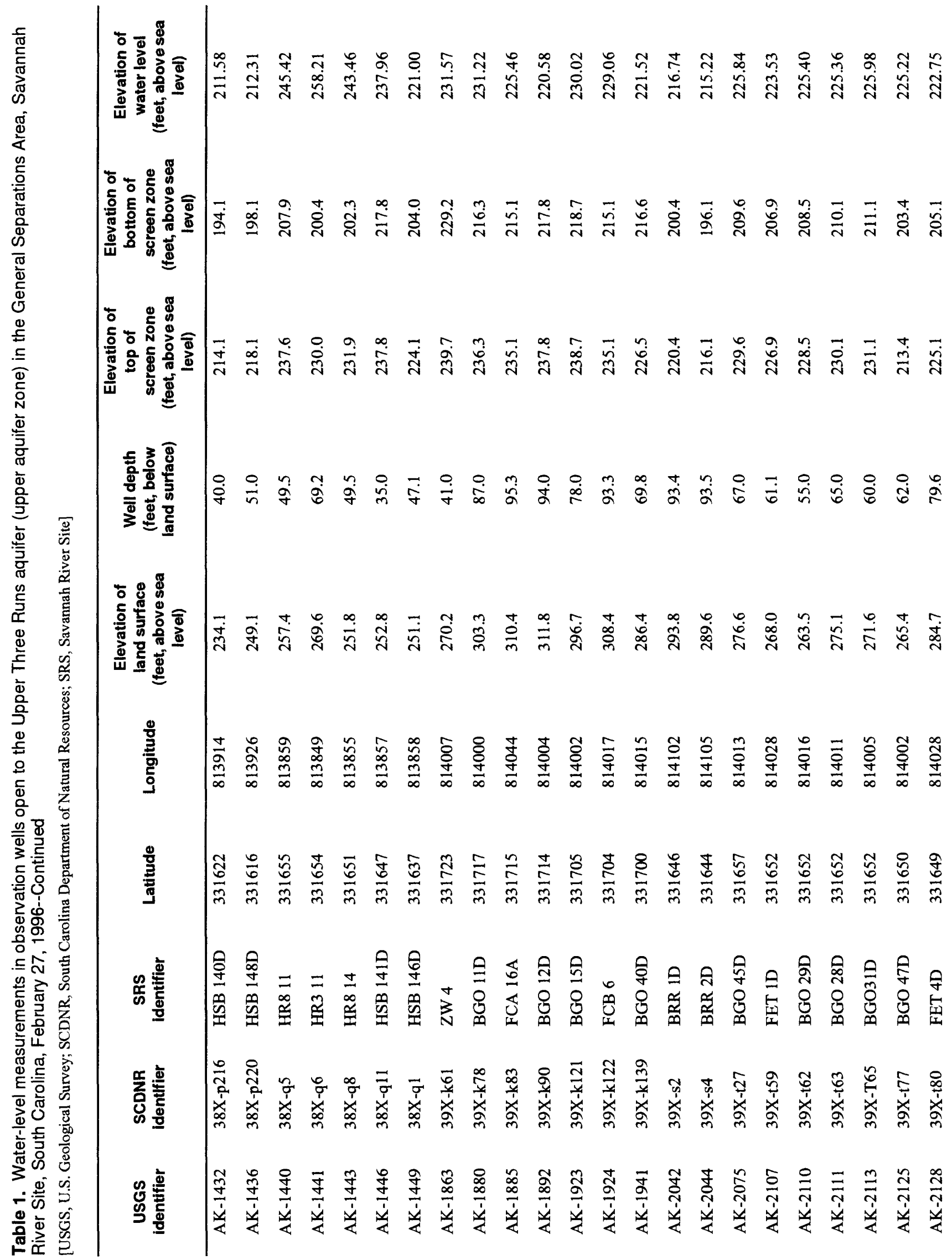

34 Ground-Water Levels in the Upper Three Runs and Gordon Aquifers in the General Separations Area, Savannah River Site, South Carolina, 1996 


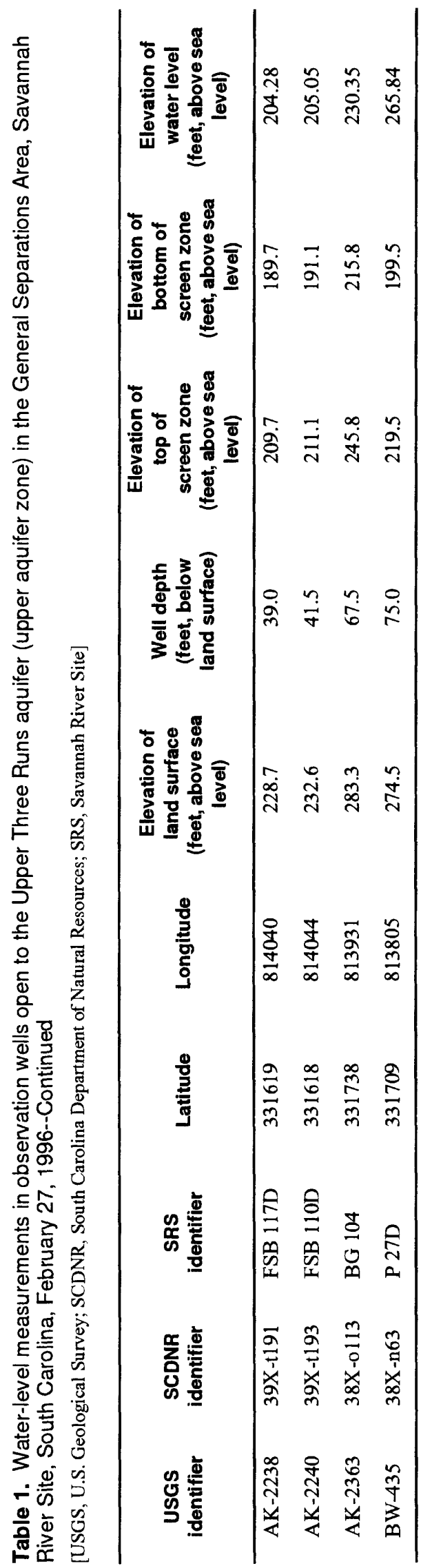

36 Ground-Water Levels in the Upper Three Runs and Gordon Aquifers in the Generai Separations Area, Savannah River Site, South Carolina, 1996 


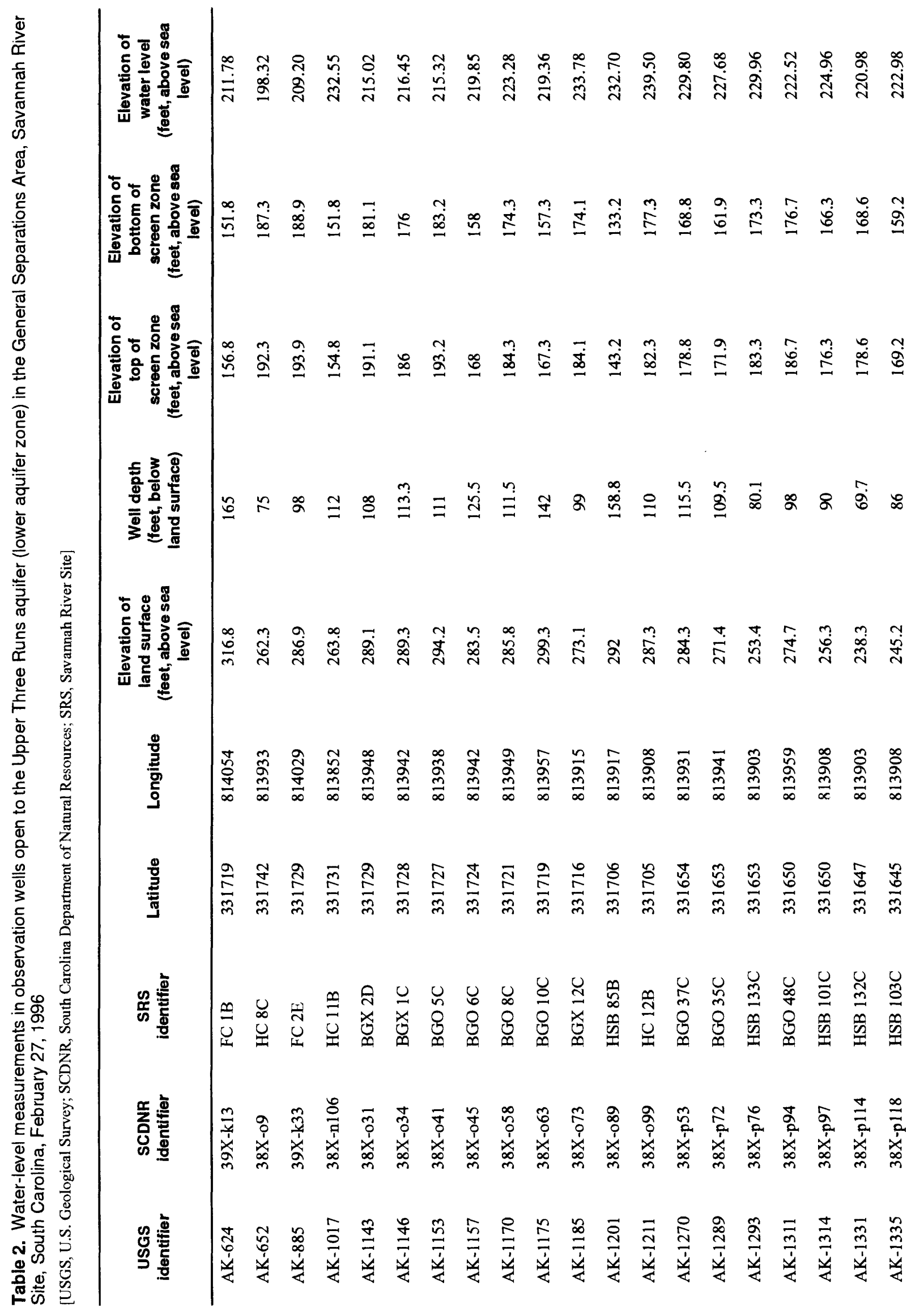




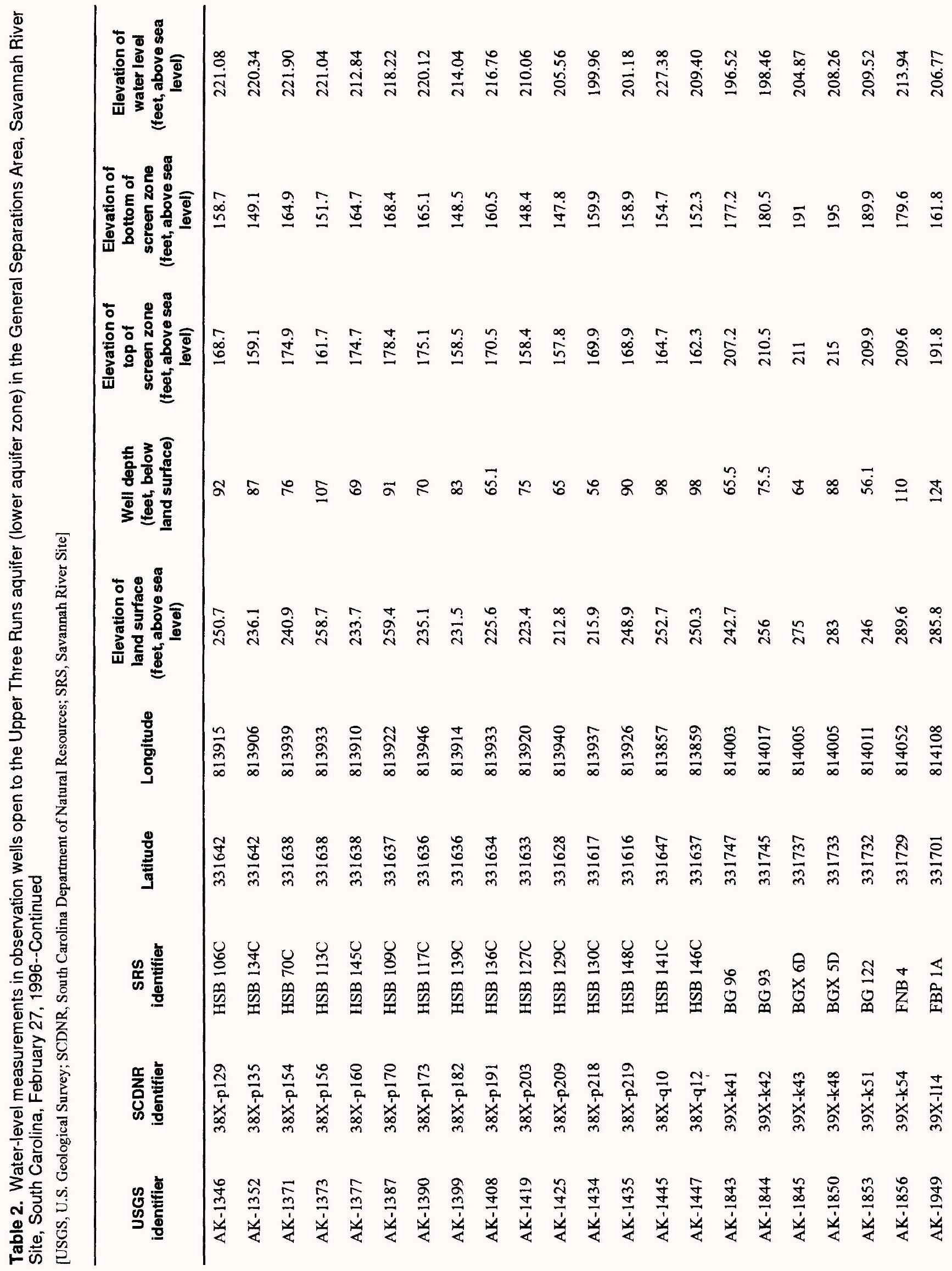

38 Ground-Water Levels in the Upper Three Runs and Gordon Aquifers in the General Separations Area, Savannah River Site, South Carolina, 1996 







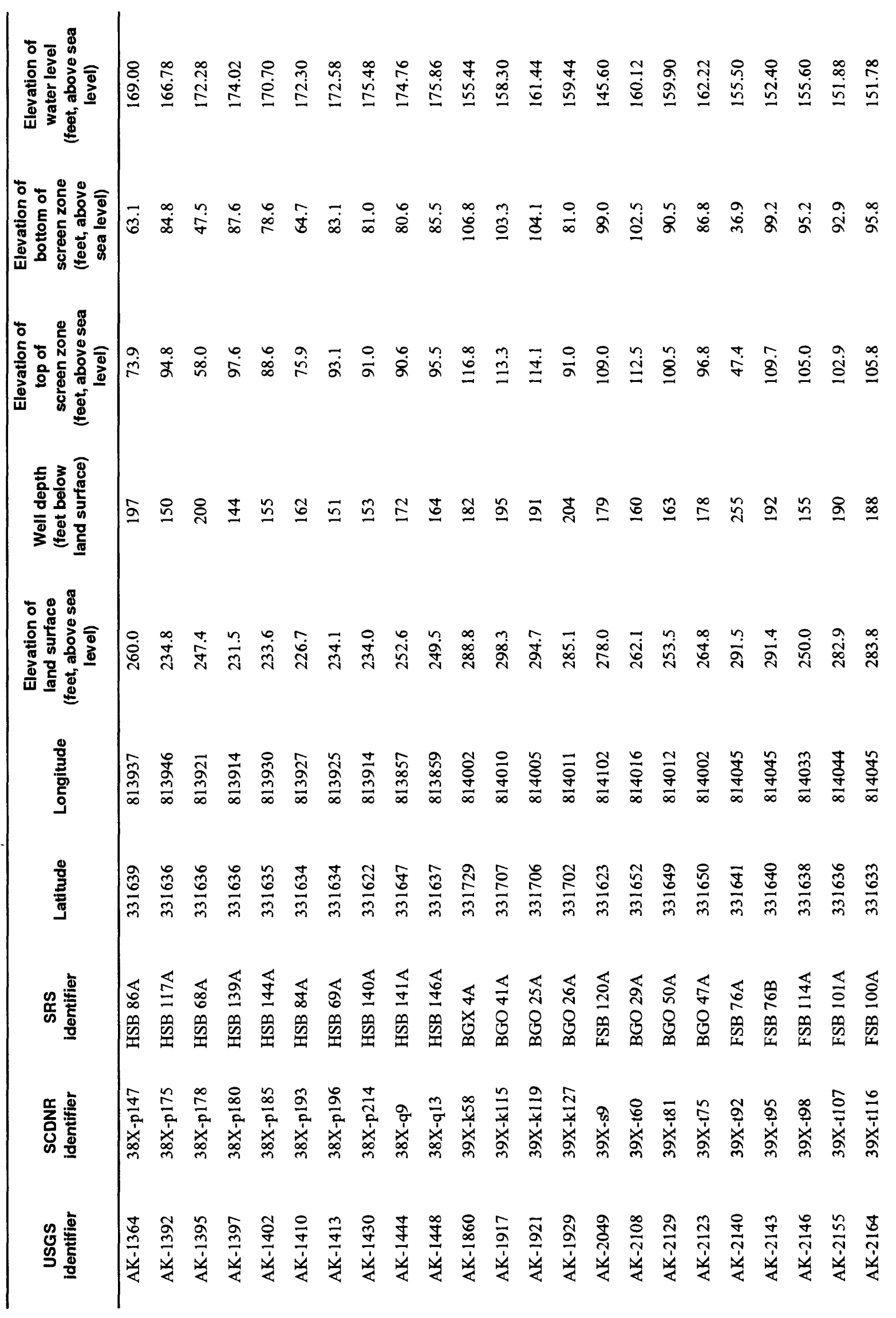




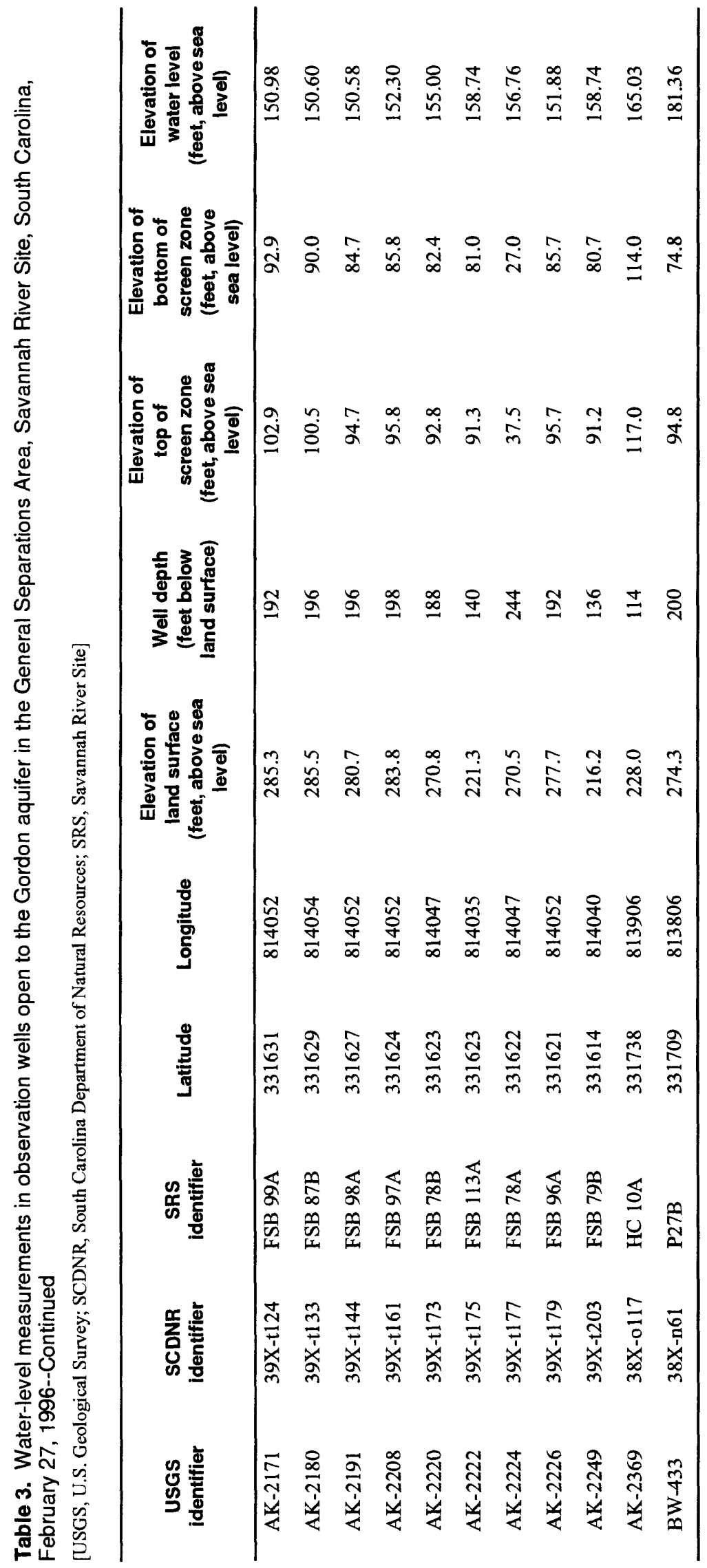




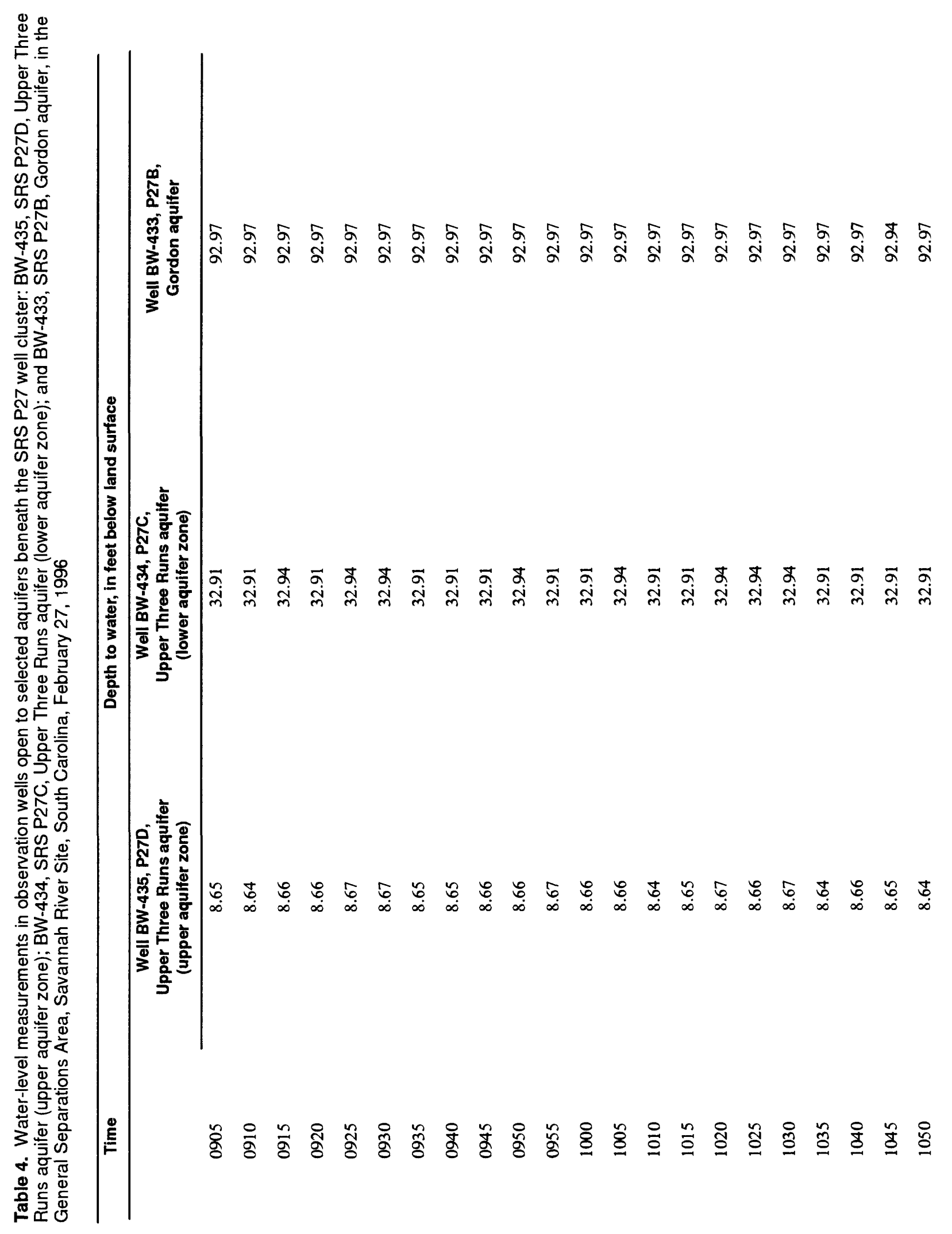




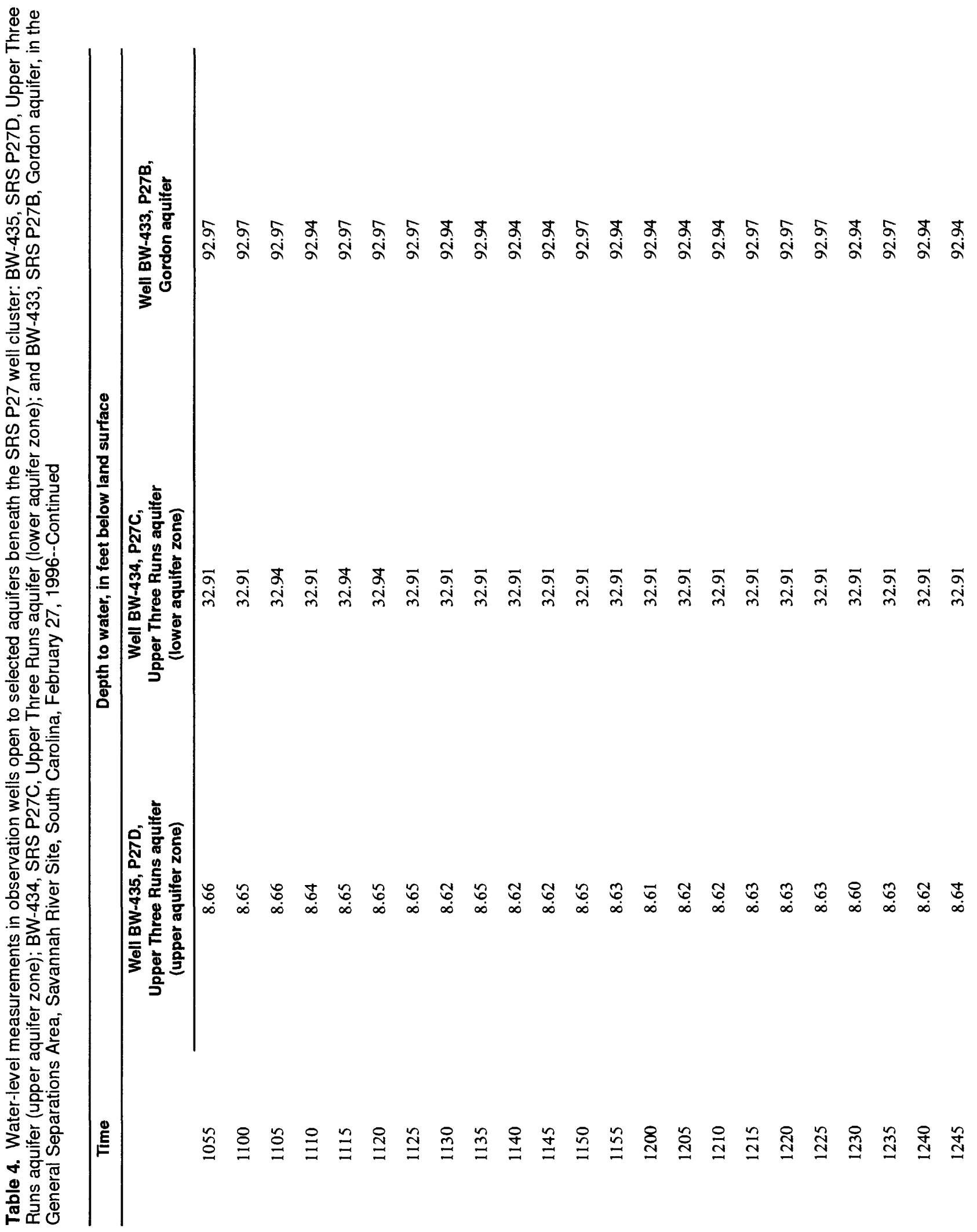

44 Ground-Water Levels in the Upper Three Runs and Gordon Aquifers in the General Separations Area, Savannah River Site, South Carolina, 1996 


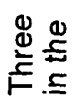

든

옥홍

官

원

क ठ

s

นึญ

Y

品岳

ัั

㟧

긍

市

N

凹

$\frac{\pi}{5}$

क

我怘

동

बे

은

屯은

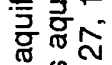

ชั

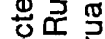

屯 ڤ

요

더 ఏ등

응욕융

娄

등

茜告紊

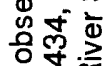

잉 $\frac{1}{\pi}$

욛ㅇ

ह

就

ญั

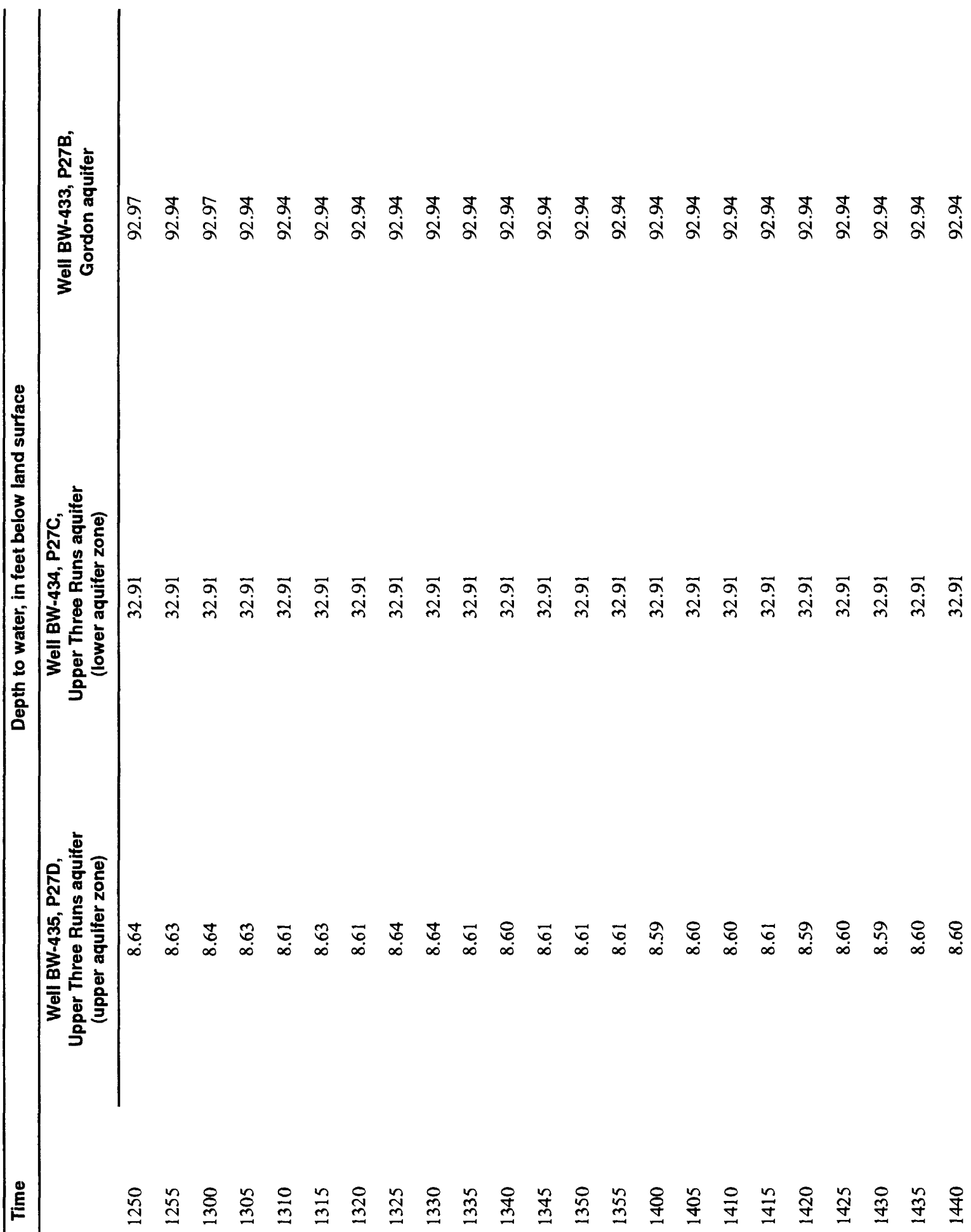

म 苗

응

竚 


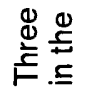

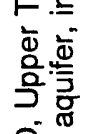

กั

ญํㅡㅁ

क

के

นึิ

?

品

迎

긍

可

ลิ

क

的

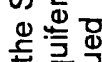

点

ळ

인

흉요

爱尔

는

둥 줄

这

다유

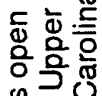

क0

등

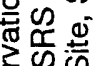

的

苍 ऐं

$\subseteq 3$

可需

Фั人

잉

N

ฐొ

哥

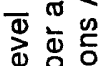

훈을음

舫

3

ช 휴

ฟิ

ฟ

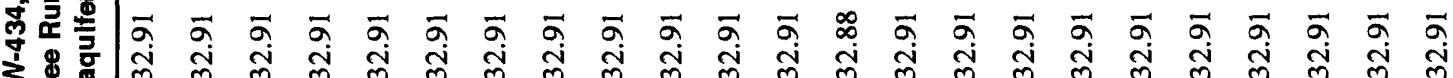




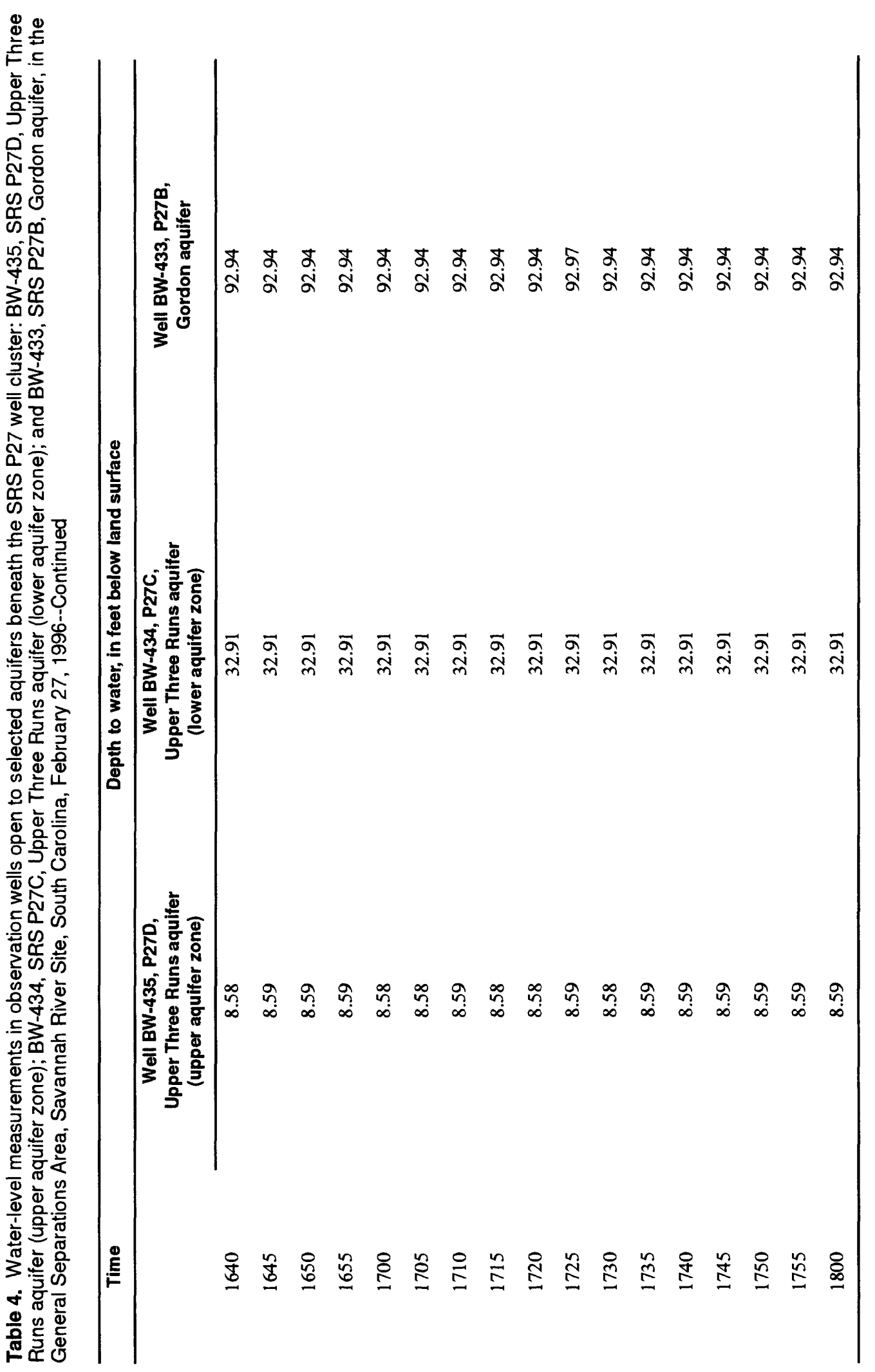




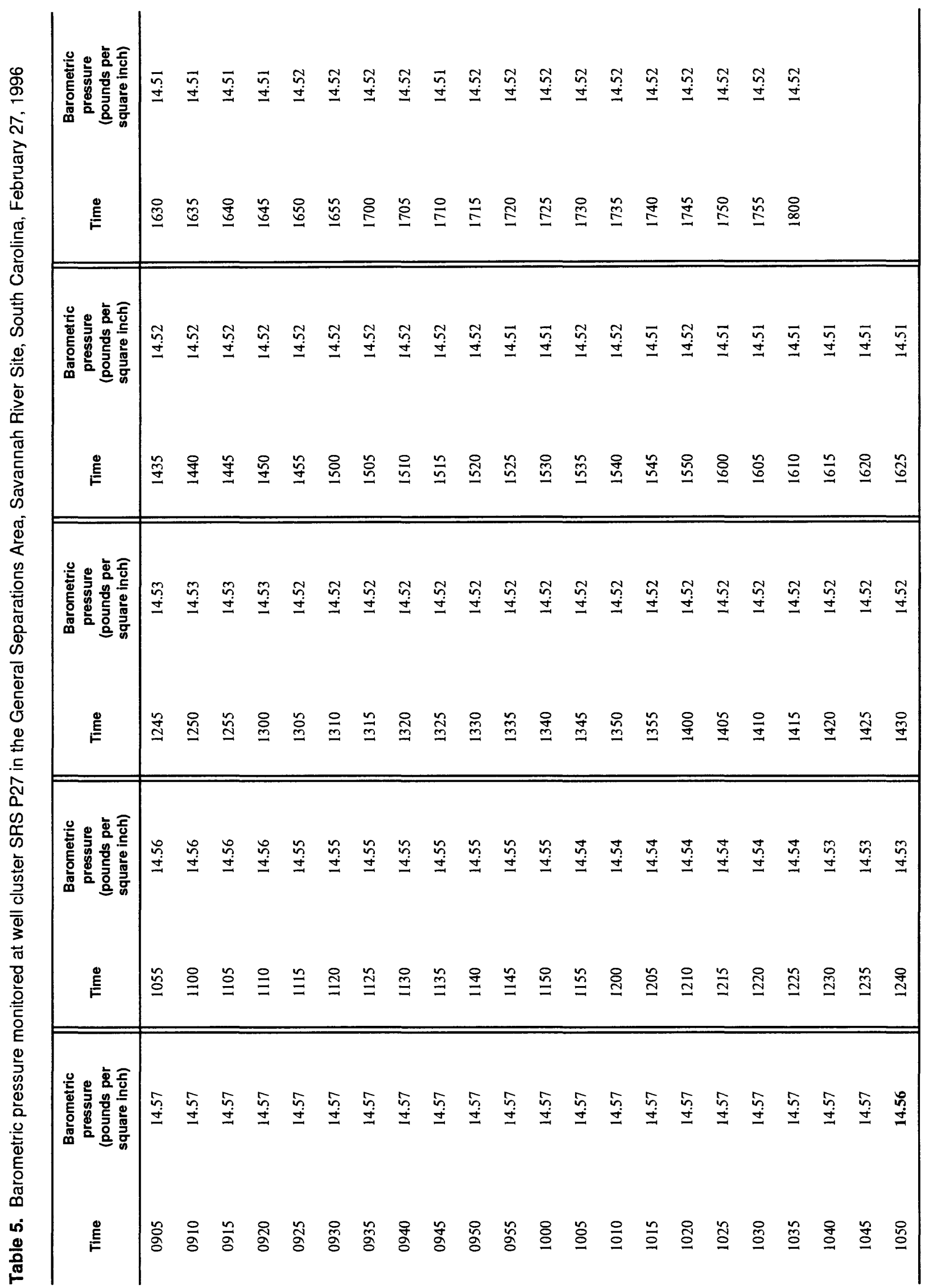

48 Ground-Water Levels in the Upper Three Runs and Gordon Aquifers in the General Separations Area, Savannah River Site, South Carolina, 1996 


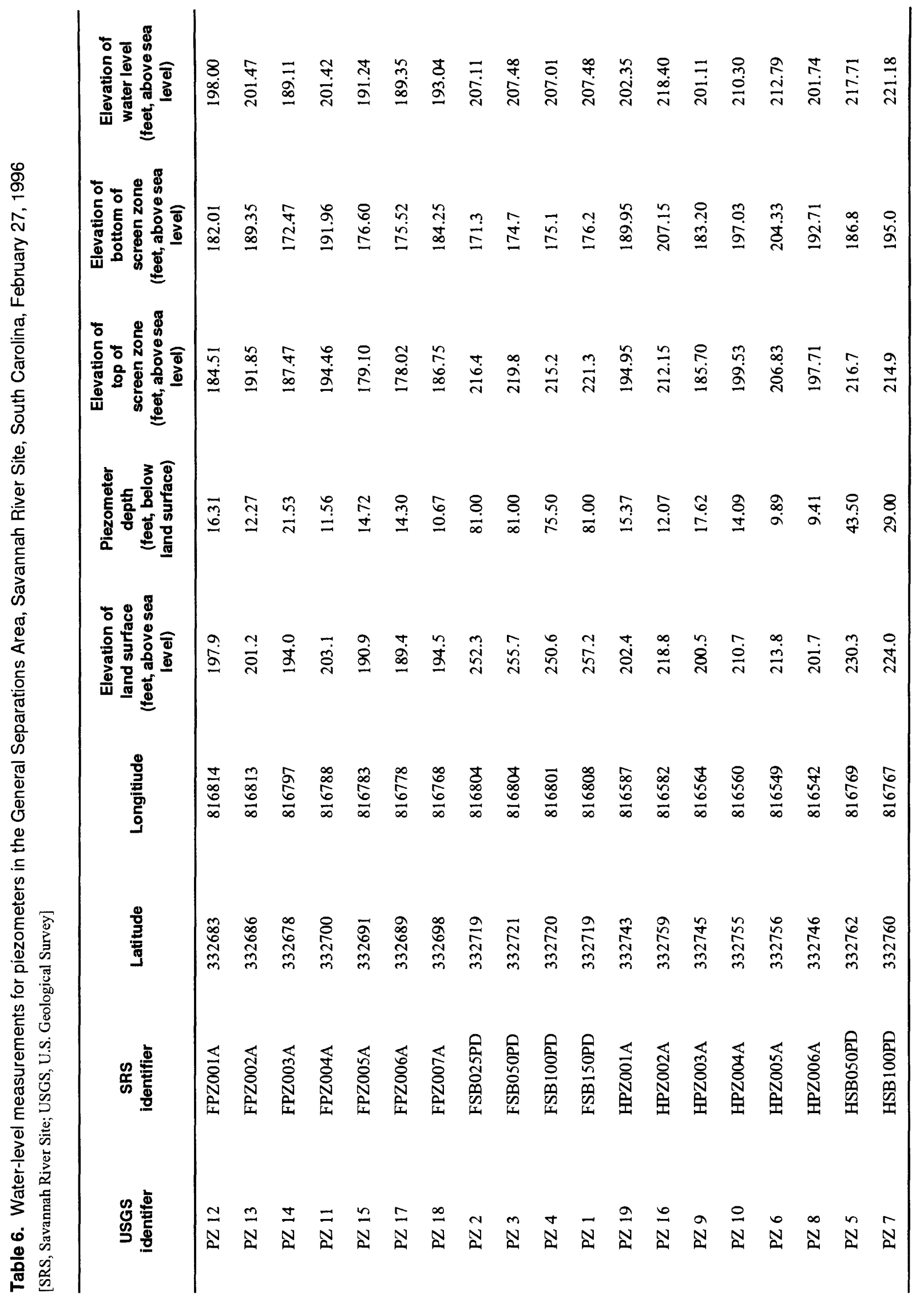


Table 7. Surface-water elevation measurements at selected surface-water sites in the General Separations Area, Savannah River Site, South Carolina, February 27, 1996

\begin{tabular}{cccc}
\hline $\begin{array}{c}\text { Study } \\
\text { identifier }\end{array}$ & Latitude & Longitude & $\begin{array}{c}\text { Elevation of } \\
\text { water level } \\
\text { (feet, above soa level) }\end{array}$ \\
\hline SW-1 & 331706 & 814243 & 124.88 \\
SW-2 & 331740 & 814203 & 127.16 \\
SW-3 & 331602 & 814040 & 178.40 \\
SW-4 & 331622 & 814006 & 190.11 \\
SW-5 & 331620 & 813833 & 214.57 \\
SW-6 & 331752 & 813743 & 275.82 \\
SW-7 & 331744 & 813053 & 201.14 \\
SW-8 & 331826 & 813751 & 173.86 \\
SW-9 & 331900 & 813819 & 155.18 \\
SW-10 & 331833 & 813945 & 143.24 \\
SW-11 & 331749 & 813919 & 170.09 \\
SW-12 & 331802 & 813942 & 146.94 \\
SW-13 & 331805 & 814029 & 135.06 \\
SW-14 & 331623 & 814005 & 190.64 \\
SW-15 & 331631 & 813912 & 203.96 \\
SW-16 & 331745 & 813753 & 201.19 \\
\hline & & & \\
\hline & & & \\
\hline
\end{tabular}

